Research Plan for the Investigation of Water, Energy, and Biogeochemical Budgets in the Luquillo Mountains, Puerto Rico

By Matthew C. Larsen, Paul D. Collar, and Robert F. Stallard

U.S. GEOLOGICAL SURVEY

Open-File Report 92-150 


\section{U.S. DEPARTMENT OF THE INTERIOR BRUCE BABBITT, Secretary}

U.S. GEOLOGICAL SURVEY

Dallas L. Peck, Director

Any use of trade, product, or firm names in this publication is for descriptive purposes only and does not imply endorsement by the U.S. Geological Survey.

For additional information write to:

District Chief

U.S. Geological Survey

P.O. Box 364424

San Juan, Puerto Rico 00936-4424
Copies of this report can be purchased from:

U.S. Geological Survey

Books and Open-File Reports Section

Federal Center, Box 25425

Denver, CO 80225-0425 


\section{CONTENTS}

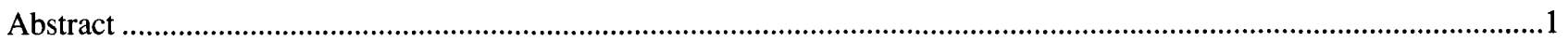

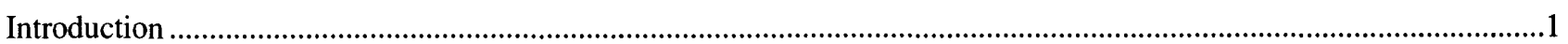

Purpose and scope

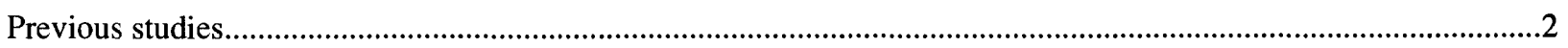

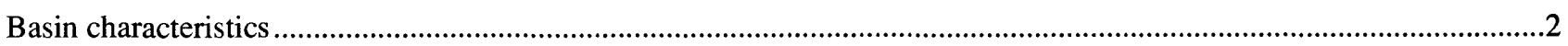

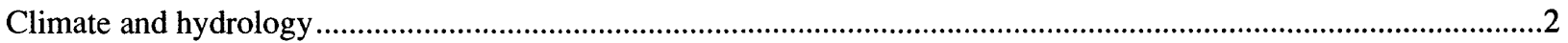

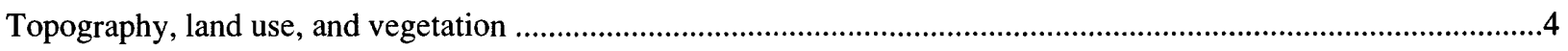

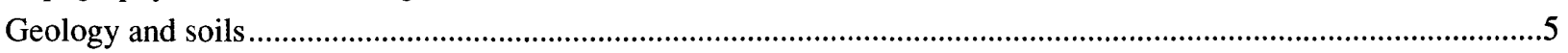

Research plan for the investigation of water, energy, and biogeochemical budgets .........................................................5

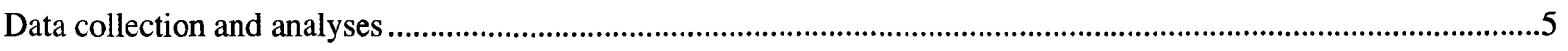

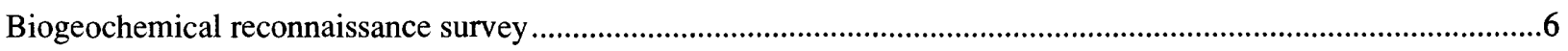

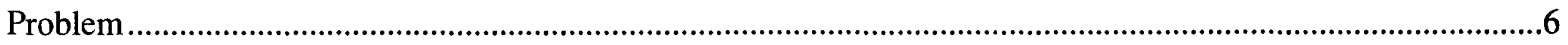

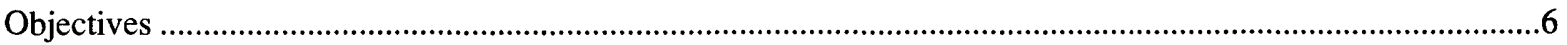

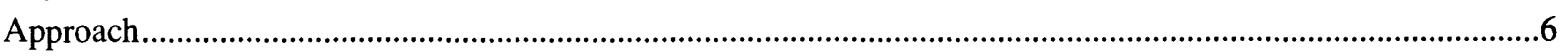

Biogeochemical budgets: water, energy, nutrient, dissolved solids,

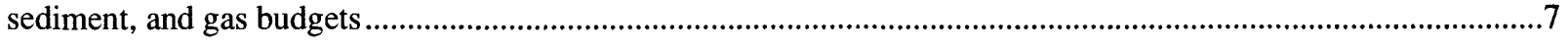

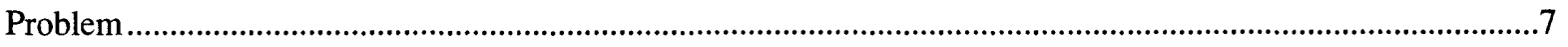

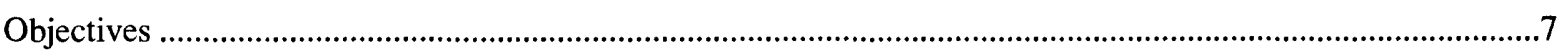

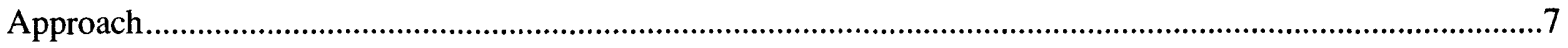

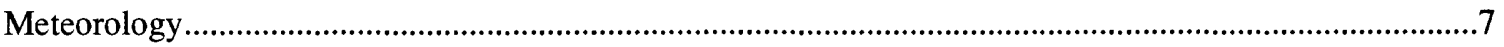

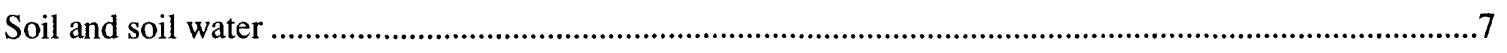

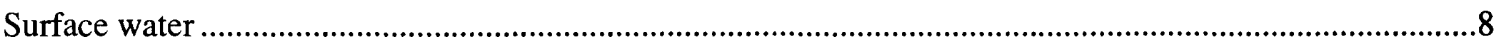

Ground water

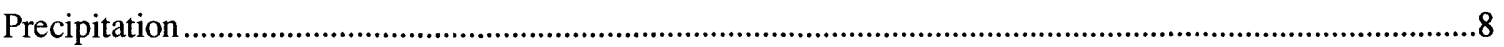

Weathering, erosion, and mass-wasting processes in undeveloped watersheds

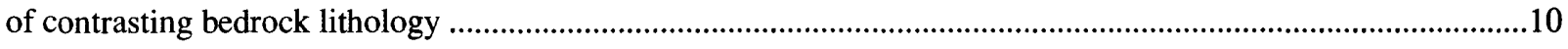

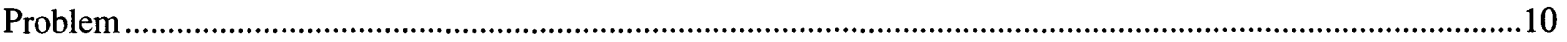

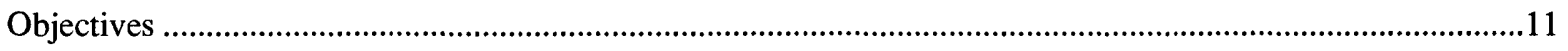

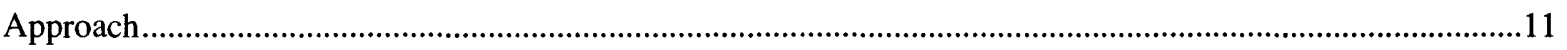

Comparison of weathering and gas flux in developed and forested watersheds ....................................................12

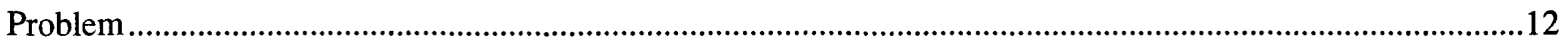

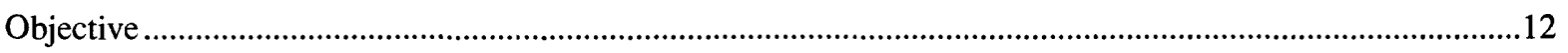

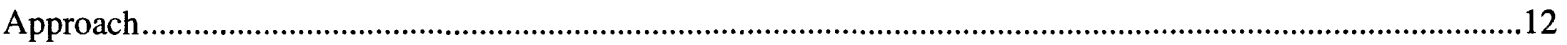

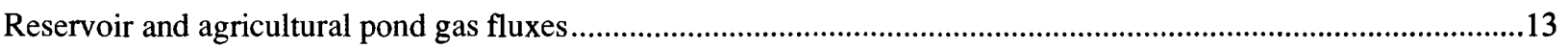

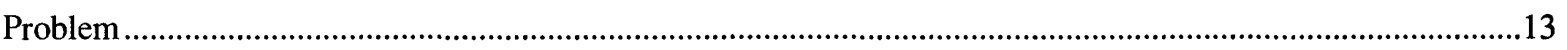

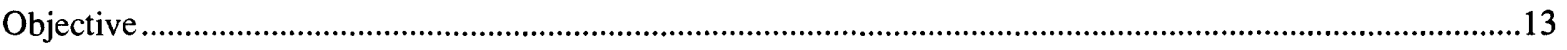

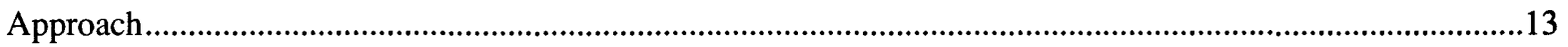

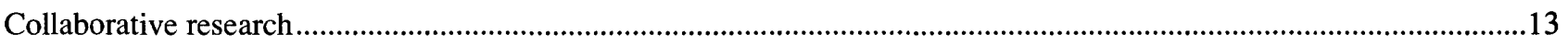

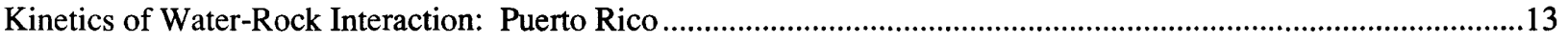

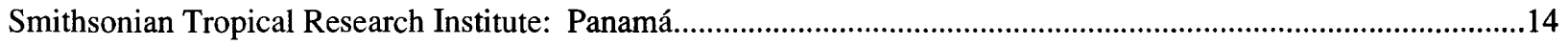

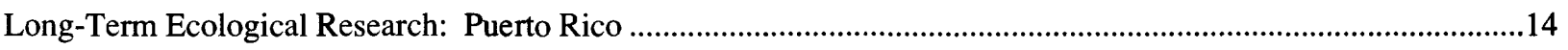

Puerto Rico Department of Natural Resources/University of Puerto Rico ...................................................................15 
U.S. Geological Survey/ Puerto Rico Aqueduct and Sewer Authority Lago Loíza Basin Uplands Erosion

Centre National de la Recherche Scientifique, Campus Orsay, France _......................................................................15

Center for Marine Science, University of Southern Mississippi, Stennis Space Center ………..................................15

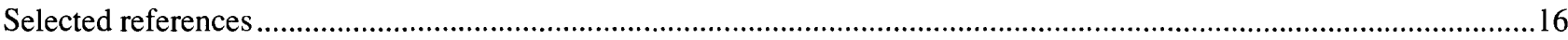

\section{FIGURES}

1. Map showing study watersheds and bedrock type in the Río Grande de Loíza basin and the Luquillo Experimental Forest, northeastern Puerto Rico

2. Map showing location of streamflow gaging stations and meteorological stations in and near the Río Grande de Loíza basin and the Luquillo Experimental Forest, northeastern Puerto Rico

3. Photograph of a reach of the Río Icacos, 200 meters upstream from the U.S. Geological Survey streamflow gaging station, showing streamflow during base-flow conditions

\section{TABLES}

1. Streamflow characteristics and years of record for selected streams draining the Luquillo

Experimental Forest

2. Streamflow characteristics and years of record for selected streams draining the Río Grande de Loíza basin

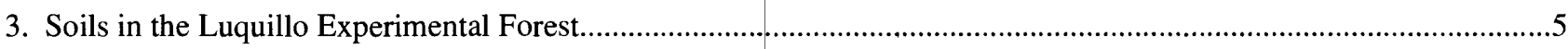

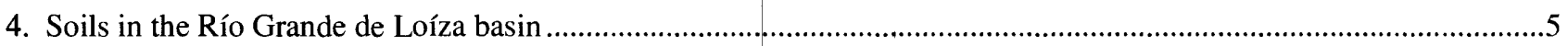

5. Workplan for the Puerto Rico Water, Energy, and Biogeochemical Budgets study ...............................................6 


\begin{tabular}{rll}
\hline Multiply & By & To obtain \\
\hline millimeter $(\mathrm{mm})$ & 0.03937 & inch \\
centimeter $(\mathrm{cm})$ & 0.3937 & inch \\
meter $(\mathrm{m})$ & 3.281 & foot \\
kilometer $(\mathrm{km})$ & 0.6214 & mile \\
centimeter per hour $(\mathrm{cm} / \mathrm{h})$ &, 3937 & inch per hour \\
hectare $(\mathrm{ha})$ & 0.003861 & square mile \\
square kilometer $\left(\mathrm{km}^{2}\right)$ & 0.3861 & square mile \\
cubic meter per second $\left(\mathrm{m}^{3} / \mathrm{s}\right)$ & 35.31 & cubic foot per second \\
\hline
\end{tabular}

Temperature in degrees Fahrenheit $\left({ }^{\circ} \mathrm{F}\right)$ may be converted to degrees Celsius $\left({ }^{\circ} \mathrm{C}\right)$ as follows: ${ }^{\circ} \mathrm{C}=5 / 9\left({ }^{\circ} \mathrm{F}-32\right)$

\section{Acronyms used in this report:}

Institute of Tropical Forestry (ITF)

Luquillo Experimental Forest (LEF)

National Research Program (NRP)

U.S. Geological Survey (USGS)

Smithsonian Tropical Research Institute (STRI)

Water, Energy, and Biogeochemical Budgets (WEBB) 


\title{
Research Plan for the Investigation of Water, Energy, and Biogeochemical Budgets in the Luquillo Mountains, Puerto Rico
}

\author{
By Matthew C. Larsen, Paul D. Collar, and Robert F. Stallard
}

\section{Abstract}

The Luquillo mountains of eastern Puerto Rico are the site of U. S. Geological Survey research into biogeochemical and geomorphic processes that control the movement and transformation of water, energy, bedrock weathering products, and nutrients in the earth-surface environment. This study was begun in 1990 and is scheduled to last three years, with the possibility of being extended for further data collection. The study area for this research effort includes the 113 square kilometer Luquillo Experimental Forest that is administered by the U.S. Forest Service. The Luquillo Experimental Forest has been the site of ongoing research since 1988, as part of the National Science Foundation's Long Term Ecological Research program. In addition, comparative studies are being conducted in the Río Grande de Loíza basin (Loíza basin), an urban and agriculturally developed 600 square kilometer watershed located immediately to the west of the Luquillo Experimental Forest.

The principal elements of the study described in the report are as follows:

1. Determination of biogeochemical budgets: water, energy, carbon, nutrient, ion, sediment, and gas budgets will be calculated in two Luquillo Experimental Forest watersheds instrumented with meteorologic, soil, hydrologic, and groundwater monitoring equipment. A monthly time series of samples is being collected. In addition, intensive sampling is undertaken during selected storms.

2. Study of weathering, mass-wasting and mass-storage processes in undeveloped watersheds of contrasting lithology: chemical-weathering, erosion, and mass-wasting processes in watersheds underlain by the two dominant rock types (volcaniclastic and quartz diorite) are being compared. The effects of mass wasting on biogeochemical cycling in each rock type will be evaluated through a compilation of physical, chemical, and mineralogic properties for a chronosequence of landslides. Water and sediment budgets will be used to develop a conceptual model of hillslope hydrology and landform evolution.

3. Comparison of weathering and gas fluxes in developed and forested watersheds: paired basins were selected and gaged in the relatively undisturbed Luquillo Experimental Forest and in the agriculturally developed Loíza basin. Budgets of all major aqueous constituents will be compared and contrasted in the developed and forested basins of similar lithology.

4. Measurement of reservoir and agricultural pond gas fluxes: methane production is being measured in selected reservoirs and agricultural ponds in and near the Loíza basin and Luquillo Experimental Forest. A regional methane budget will be calculated.

\section{INTRODUCTION}

Understanding and predicting global environmental change has become a major social and scientific concern of the late 20 th century. Scientists from many disciplines and nations around the world have mobilized in this endeavor. During the past three decades, atmospheric scientists have made substantial progress in developing models that account for most of the important components of the climate system. Significant progress is needed, however, in the understanding of the processes associated with the exchanges of water, energy, and carbon between the earth's surface (including vegetation) and the atmosphere. Progress in this latter area requires the knowledge and skills of specialists in fields such as hydrology, biology, geology, and geochemistry, as well as the atmospheric sciences.

To strengthen biogeochemical investigations of ecological systems and the dynamics of the interactions of water, energy, nutrients, and gases, the U.S. Geological Survey (USGS) 
Global Change Research Program initiated a nationwide program entitled Water, Energy and Biogeochemical Budgets (WEBB). The purpose of WEBB is twofold: to improve understanding of processes controlling terrestrial water, energy and biogeochemical fluxes, process interactions, and process relations to climatic variables; and to improve the capability to predict terrestrial water, energy, and biogeochemical budgets over a range of spatial and temporal scales. This study was begun in 1990 and is scheduled to last three years, with the possibility of being extended for further data collection.

WEBB process studies are being implemented as a systematic program of intensive, long-term field investigations in Colorado, Georgia, Puerto Rico, Vermont, and Wisconsin. Study sites were selected on the basis of geographical and environmental diversity. Sites having extant parallel data collection or WEBB-related process investigations were given priority. The sites include multidisciplinary research locations, such as the National Science Foundation sponsored Long-Term Ecological Research sites, the U.S. Forest Service Experimental Forests, and the United Nations Educational, Scientific, and Cultural Organization study areas known as International Biosphere Reserves. A major emphasis of WEBB investigations is the development and maintenance of strong collaborative research relationships among scientists in other Federal agencies and the academic community.

Research at the Puerto Rico WEBB site addresses the biogeochemistry of weathering and erosion in the Luquillo mountains. The research will focus on how mass wasting and other hillslope erosive processes control rates of erosion, the composition of solid and dissolved erosion products, and nutrient and carbon dynamics in the soils of the watershed. This research is accomplished by the development of biogeochemical budgets based on regular monthly sampling and storm sampling, the study of hillslope geomorphic and hydrologic processes, and the study of biogeochemical processes in soils. In addition, the effects of agricultural development on nutrient budgets and gas budgets will be investigated. This research problem involves a comparison between developed and undeveloped watersheds of (1) water, sediment, and nutrient budgets, and (2) gas fluxes from artificial ponds and lakes.

\section{Purpose and Scope}

This report describes the USGS research objectives for the WEBB site in the Luquillo mountains of Puerto Rico (fig. 1). The study area is briefly described and specific research methods to be used are outlined. This report serves as a planning document for the WEBB study in Puerto Rico.

\section{Previous Studies}

The Luquillo Experimental Forest (LEF) is one of the few tropical forest areas in the world that has been studied intensively and comprehensively described. Odum and Pigeon (1970) provide a detailed description of the LEF in one of the few comprehensive publications that summarize a humidtropical forest system. Two other comparable studies of humidtropical forest systems were done in Panamá (Leigh and others, 1982) and Malaysia (Malayan Nature Society, 1978).

Numerous time-series of meteorologic, hydrologic, ecologic, sociopolitic, and miscellaneous data are available for the LEF and are listed in separate publications (Brown and others, 1983; Mosquera and Feheley, 1984). Previous meteorologic data in the LEF includes those collected by Bogart and others (1964), Briscoe (1966), Baynton (1968), Odum and others (1970), and Scatena (1989 and 1990). Soil-water availability and movement have been studied by Lugo-López and others (1968), Edmisten (1970), and Jordan (1970a and 1970b). Studies of soil-moisture responses to rainfall in the LEF are limited (Larsen and Torres-Sánchez, 1990), although soilmoisture responses to rainfall on other Caribbean islands have been studied by Anderson and Burt (1978), Anderson and Kneale (1980), and Anderson (1983). Variable weathering rates of the differing bedrock lithologies in the LEF and elsewhere in the humid tropics are well documented (Beaven and Dumbleton, 1966; Dixon and Robertson, 1970; Beinroth, 1971; Deere and Patton, 1971; Boccheciamp, 1977; Beinroth, 1982; Stallard, 1988). Weathering processes in alluvium derived from the San Lorenzo batholith in southeastern Puerto Rico preliminarily have been described by Collar and others (1990).

\section{BASIN CHARACTERISTICS}

The study area consists of parts of the Río Mameyes (17.8 $\mathrm{km}^{2}$ ) and Río Icacos $\left(3.3 \mathrm{~km}^{2}\right)$ basins in the $113 \mathrm{~km}^{2} \mathrm{LEF}$, and parts of the Río Cayaguás $\left(26.4 \mathrm{~km}^{2}\right)$ and Río Canóvanas $(25.5$ $\mathrm{km}^{2}$ ) basins in northeastern Puerto Rico (fig. 1). The climatologic, geologic, and topographic characteristics of these basins and of Puerto Rico are highly variable. These characteristics are described in the following sections along with soils and landuse history in the Luquillo mountains.

\section{Climate and Hydrology}

The island of Puerto Rico is situated at the eastern end of the Greater Antilles, 1,700 km southeast of Miami, Florida, and is located in the path of the easterly tradewinds. These winds 


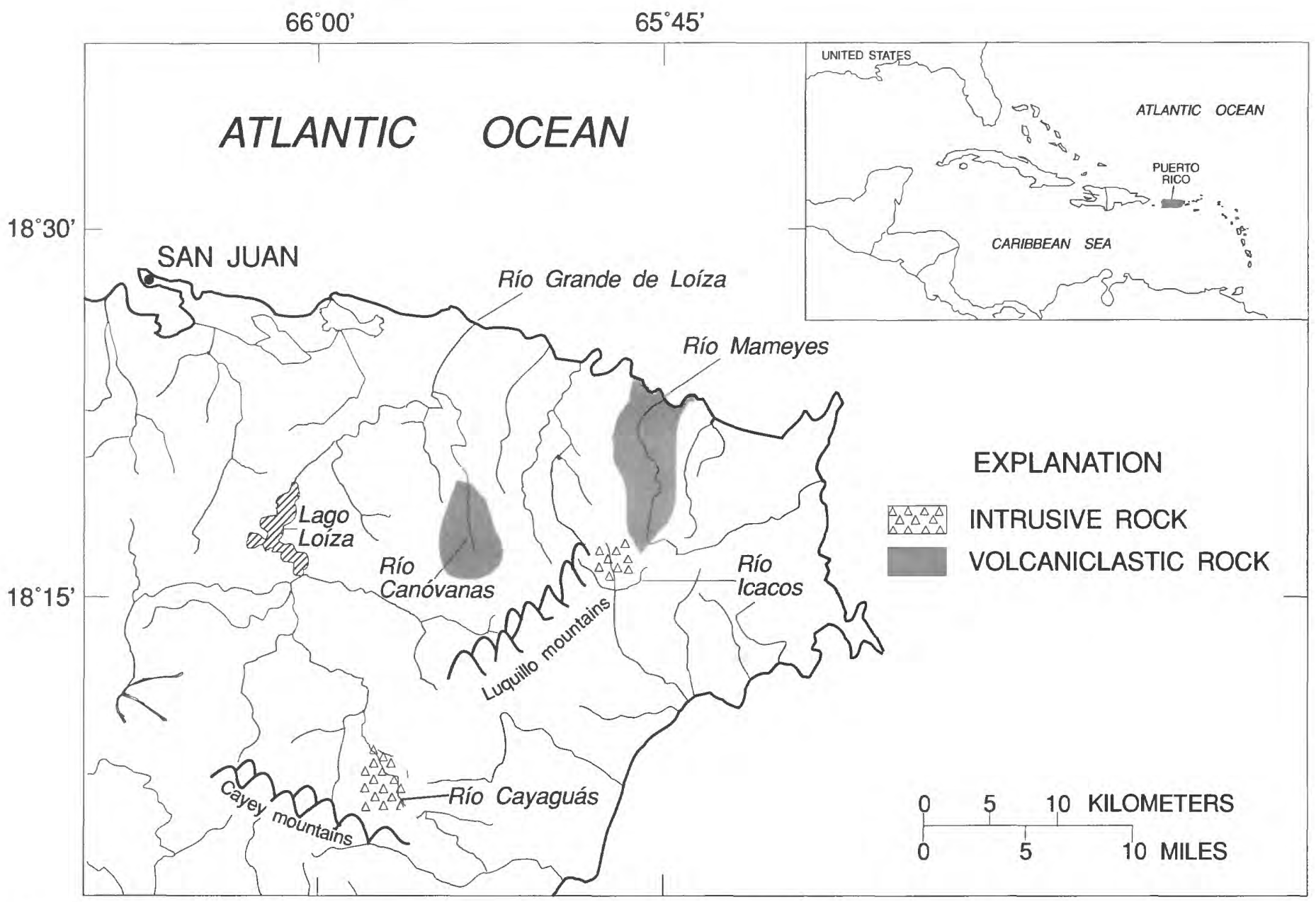

Figure 1. Study watersheds and bedrock type in the Río Grande de Loiza basin and the Luquillo Experimental Forest, northeastern Puerto Rico.

dominate regional climate and are strongest during the wet season months of May through December (Calvesbert, 1970). As much as 70 percent of the yearly rainfall is delivered by tropical waves, depressions, storms, and hurricanes imbedded in the easterly tradewinds. The climate of the Luquillo mountains is humid-tropical, and 5 to 10 percent of annual rainfall occurs each month. Mean-annual temperature varies with elevation, from $19^{\circ} \mathrm{C}$ at the highest peaks, to $27^{\circ} \mathrm{C}$ along the coastal plains (Calvesbert, 1970). Mean annual precipitation ranges from $3,500 \mathrm{~mm}$ to as much as $5,000 \mathrm{~mm}$, due to orographic effects (Brown and others, 1983). More than 1,600 rain showers per year were recorded at one site in the LEF (Odum and others, 1970), and approximately 78 percent of these showers were of 1 hour or less duration (Colón, 1983). The Luquillo mountains are the wettest part of Puerto Rico, with rainfall decreasing to the west and south. Mean-annual rainfall in the Loíza basin ranges from 1,500 to $2,500 \mathrm{~mm}$.

An average of nine tropical disturbances affect the Caribbean each year (Musk, 1988). These disturbances occur between May and November (Calvesbert, 1970) and originate over the Atlantic Ocean near the African continent. Another important source of rain in Puerto Rico is cold fronts that originate in the north polar region during winter months and reach Puerto Rico after moving south across the North American continent. Northerly cold fronts can deliver heavy and continuous rainfall sometimes lasting for several days (Calvesbert, 1970).

Streams draining the LEF have relatively small drainage areas and high runoff (table 1). The Río Grande de Loíza, which drains the area just west of the LEF, has the largest drainage basin in Puerto Rico and less runoff than the LEF 
(table 2). As much as 80 percent of annual sediment load in the Luquillo mountains is transported during 5 to 10 days of storminduced peak discharge (Scatena, 1990; W. McDowell, University of New Hampshire, written commun., 1991).

Table 1. Streamflow characteristics and years of record for selected streams draining the Luquillo Experimental Forest (López and others, 1979; Curtis and others, 1991)

$\left[\mathrm{km}^{2}\right.$, square kilometer; $\mathrm{m}^{3} / \mathrm{s} / \mathrm{km}^{2}$, cubic meter per second per square kilometer; mm, millimeters]

\begin{tabular}{ccccc}
\hline $\begin{array}{c}\text { Name of } \\
\text { stream }\end{array}$ & $\begin{array}{c}\text { Years } \\
\text { of } \\
\text { record }\end{array}$ & $\begin{array}{c}\text { Drainage } \\
\text { area in } \\
\mathrm{km}^{2}\end{array}$ & $\begin{array}{c}\text { Unit } \\
\text { discharge } \\
\text { in } \mathrm{m}^{3} / \mathrm{s} / \mathrm{km}^{2}\end{array}$ & $\begin{array}{c}\text { Average } \\
\text { annual } \\
\text { runoff in } \mathrm{mm}\end{array}$ \\
\hline Río Icacos & 19 & 3.3 & 0.13 & 4,052 \\
Río Mameyes & 14 & 17.8 & 0.09 & 2.893 \\
\hline
\end{tabular}

Table 2. Streamflow characteristics and years of record for selected streams draining the Río Grande de Loíza basin (López and others, 1979; Curtis and others, 1991)

$\left[\mathrm{km}^{2}\right.$, square kilometer; $\mathrm{m}^{3} / \mathrm{s} / \mathrm{km}^{2}$, cubic meter per second per square kilometer; mm, millimeters; **, flow regulated by upstream dam]

\begin{tabular}{ccccc|}
\hline $\begin{array}{c}\text { Name of } \\
\text { stream }\end{array}$ & $\begin{array}{c}\text { Years } \\
\text { of } \\
\text { record }\end{array}$ & $\begin{array}{c}\text { Drainage } \\
\text { area in } \\
\mathrm{km}^{2}\end{array}$ & $\begin{array}{c}\text { Unit } \\
\text { discharge } \\
\mathrm{in}^{3} / \mathrm{s} / \mathrm{km}^{2}\end{array}$ & $\begin{array}{c}\text { Average } \\
\text { annual } \\
\text { runoff in } \mathrm{mm}\end{array}$ \\
\hline $\begin{array}{c}\text { Río Grande de } \\
\text { Loíza }\end{array}$ & 6 & 541 & $0.02^{* *}$ & $484 * *$ \\
Río Cayaguás & 14 & 26.4 & 0.05 & 1,505 \\
Río Canóvanas & 24 & 25.5 & 0.03 & 981 \\
\hline
\end{tabular}

\section{Topography, Land Use, and Vegetation}

The Luquillo mountains are characterized by rugged topography and a maximum elevation of $1,074 \mathrm{~m}$ above sea level. The steep slopes are highly dissected by perennial and ephemeral streams, and the mountains are fringed by a relatively flat coastal plain, 8 to $16 \mathrm{~km}$ wide. The LEF is located in the uplands of the Luquillo mountains. The southern and eastern parts of the Loíza basin are also in the Luquillo mountains uplands. Much of the remaining area of the Loíza basin consists of low hills, alluvial valleys, and the Cayey mountains (fig. 1), on the western side of the watershed.

Because of three centuries of extensive agriculture, as much as 90 percent of the Loíza basin had been deforested by the late 1940's (Birdsey and Weaver, 1987). Since that time, a shift away from agriculture towards industry has resulted in the abandonment of large areas of pasture and farmland. By the 1980 's, approximately 60 percent of the Loíza basin was deforested (Birdsey and Weaver, 1987). Extensive urbanization in the Loíza basin near the San Juan metropolitan area has occurred in recent years. The population of Caguas, located in central Loíza basin, increased 23 percent between 1970 and 1980; the number of housing units increased by 42 percent during the same period (U.S. Department of Commerce, 1982).

Four forest zones have been described in the LEF: subtropical wet forest, subtropical rain forest, lower montane wet forest, and lower montane rain forest (Ewel and Whitmore, 1973). Each zone is a major vegetation type that results from variations in elevation, mean-annual rainfall, and topography. The lower elevations below $600 \mathrm{~m}$ are dominated by tabonuco (Dacryodes excelsa), which is common on well-drained ridges (Brown and others, 1983). Above the cloud base-level of $600 \mathrm{~m}$, palo colorado (Cyrilla racemiflora) is common on welldrained, gentle slopes and ridgetops. The mountain palm (Prestoea montana) is abundant in this same elevation zone, in areas of poor drainage and steep slopes. The highest parts of the LEF consist of dwarf forest, an assemblage of dense stands of short, small diameter trees that are exposed to near-constant wind, relatively lower temperature and sunlight, and the highest mean-annual rainfall on the island.

Forest structure and dynamics are dominated by disturbance regimęs ranging in size and effect from individual treefall gaps, to landslides, to hurricanes. The study of these disturbance regimes in the LEF is the principal objective of an ongoing National Science Foundation funded Long Term Ecological Research (LTER) project initiated in 1988. Hurricanes are estimated to pass directly over the LEF about once every 60 years (Scatena and Larsen, 1991) and are thought to be the dominant control on the forest ecology. Larsen and TorresSánchez (1992) reported that rainfall-triggered landslides may disturb as much as 1.1 percent of the forested hillslope area each century. The scars caused by these landslides are estimated to require as much as 60 years before vegetation is fully recovered on the affected area (Guariguata, 1990).

Hurricane Hugo caused significant damage to the LEF in 1989 (Scatena and Larsen, 1991). Consequently, the WEBB study is being conducted during a period of net forest recovery, particularly in the Río Mameyes watershed, which was more heavily affected by Hurricane Hugo than the Río Icacos watershed. The effects of Hurricane Hugo in the Loíza basin were relatively insignificant (A. Gellis, U.S. Geological Survey, written commun., 1990). 


\section{Geology and Soils}

The Luquillo mountains are underlain largely by marinedeposited volcaniclastic rock (tuffaceous sandstone, siltstone, breccia, conglomerate, lava, and tuff) of Cretaceous-age (Briggs and Akers, 1965). Two plutons of Tertiary age, granodiorite and quartz diorite, are found in the Loíza basin and the LEF, respectively. Metamorphism in the contact zones of the Río Blanco stock and the San Lorenzo batholith has resulted in localized minor sulfide and carbonate mineralization. Four major soil associations have been mapped in the LEF (Boccheciamp, 1977; Brown and others, 1983; table 3); five major soil associations have been mapped in the Loíza basin (Boccheciamp, 1977 and 1978; table 4). Soils in the LEF and the Loíza basin generally have a high ambient soil-moisture content (36 percent of dry weight) and relatively low permeability (1.5 to 5 $\mathrm{cm} / \mathrm{h})($ Boccheciamp, 1977).

Table 3. Soils in the Luquillo Experimental Forest

\begin{tabular}{lll}
\hline \multicolumn{1}{c}{ Soil association } & \multicolumn{1}{c}{ Soil order } & \multicolumn{1}{c}{ Typical setting } \\
\hline $\begin{array}{l}\text { Caguabo-Múcara- } \\
\text { Naranjito }\end{array}$ & $\begin{array}{l}\text { Inceptisols and } \\
\text { Ultisols }\end{array}$ & Steep volcanic uplands \\
Coloso-Toa-Bajura & $\begin{array}{l}\text { Mollisols and } \\
\text { Entisols }\end{array}$ & $\begin{array}{l}\text { Level soils and flood } \\
\text { plains }\end{array}$ \\
$\begin{array}{l}\text { Los Guineos- } \\
\text { Guayabota-Rock land }\end{array}$ & $\begin{array}{l}\text { Ultisols and } \\
\text { Inceptisols }\end{array}$ & $\begin{array}{l}\text { Steeply-sloping high- } \\
\text { rainfall volcanic uplands }\end{array}$ \\
$\begin{array}{l}\text { Los Guineos-Humatas- } \\
\text { Lirios }\end{array}$ & Ultisols & $\begin{array}{l}\text { Acid soils on volcanic } \\
\text { uplands }\end{array}$ \\
\hline
\end{tabular}

\section{RESEARCH PLAN FOR THE INVESTIGATION OF WATER, ENERGY, AND BIOGEOCHEMICAL BUDGETS}

The initial phase of the WEBB program in Puerto Rico involved a geomorphic and biogeochemical survey, which was necessary to select the most appropriate watersheds for the WEBB research. After the selection of the watersheds, four principal research elements were initiated. Described in the following sections are the principal research elements and the plans for data collection, data analyses, and a reconnaissance survey. A generalized work plan for the research is outlined in table 5 .
Table 4. Soils in the Río Grande de Loíza basin

\begin{tabular}{lll}
\hline Soil association & Soil order & Typical setting \\
\hline Coloso-Toa-Bajura & $\begin{array}{l}\text { Mollisols } \\
\text { and Entisols }\end{array}$ & $\begin{array}{l}\text { Level soils and flood } \\
\text { plains }\end{array}$ \\
Caguabo-Múcara-Naranjito & $\begin{array}{l}\text { Inceptisols } \\
\text { and Ultisols }\end{array}$ & Steep volcanic uplands \\
Pandura-Rock land-Patillas & $\begin{array}{l}\text { Ultisols and } \\
\text { Inceptisols }\end{array}$ & $\begin{array}{l}\text { Steep plutonic uplands } \\
\text { Mabi-Río Arriba-Cayagua }\end{array}$ \\
$\begin{array}{l}\text { Inceptisols } \\
\text { and Alfisols }\end{array}$ & $\begin{array}{l}\text { Level to moderately } \\
\text { steep foot slopes. terraces, } \\
\text { and alluvial fans }\end{array}$ \\
Pandura-Lirios & Ultisols & $\begin{array}{l}\text { Acid soils on volcanic } \\
\text { uplands }\end{array}$ \\
\hline
\end{tabular}

\section{Data Collection and Analyses}

The data-collection program was initiated in February 1991. The types of analyses that are planned or are in progress are described below. Water samples collected as part of the study are analyzed by USGS laboratories. Streamwater, rainwater, and soil- and ground-water samples are analyzed for $\mathrm{Ca}, \mathrm{Mg}$, $\mathrm{Na}, \mathrm{K}, \mathrm{Fe}, \mathrm{Mn}, \mathrm{Si}, \mathrm{Cl}, \mathrm{Br}, \mathrm{F}$, ammonia $\left(\mathrm{NH}_{4}\right)$, sulfate $\left(\mathrm{SO}_{4}\right)$, nitrate $\left(\mathrm{NO}_{3}\right)$, nitrite $\left(\mathrm{NO}_{2}\right)$, phosphate $\left(\mathrm{PO}_{4}\right)$, alkalinity, and dissolved organic carbon. Techniques used include atomic absorption spectrometry or inductively-coupled-plasma opticalemission spectrometry for analysis of $\mathrm{Ca}, \mathrm{Mg}, \mathrm{Na}, \mathrm{K}, \mathrm{Si}, \mathrm{Fe}$, and $\mathrm{Mn}$. Ion chromatography is used for analysis of $\mathrm{NO}_{3}, \mathrm{Cl}$, and $\mathrm{SO}_{4}$. Colorimetry is used for analysis of $\mathrm{F}, \mathrm{NH}_{4}, \mathrm{NO}_{2}, \mathrm{NO}_{3}$, $\mathrm{PO}_{4}$, and total $\mathrm{P}$. Alkalinity is analyzed by titration. Specific conductance, dissolved oxygen, $\mathrm{pH}$, and temperature are measured in the field. All samples are analyzed using lowionic-strength techniques, except those soil- and ground-water samples that contain enough dissolved constituents to be analyzed with conventional procedures.

Unstable constituents are analyzed by techniques that include (1) colorimetry for analysis of nitrogen species (as $\mathrm{NO}_{2}$, $\mathrm{NO}_{3}$, and $\mathrm{NH}_{4}$ ), phosphorus species (as $\mathrm{PO}_{4}$ and total $\mathrm{P}$ ), $\mathrm{Fe} \mathrm{II}$, total-Fe, and $\mathrm{O}_{2}$; and (2) electrochemistry for analysis of $\mathrm{pH}$, $\mathrm{O}_{2}$, and specific conductance. Trace metals (Al, Sr, Ge, Ti, Zr, $\mathrm{Cu}, \mathrm{Cr}$, for example) are analyzed using atomic absorption spectrometry or inductively-coupled-plasma optical-emission spectrometry. Suspended-sediment measurements are made on all stream samples using modifications of standard USGS collection and analysis techniques (Guy, 1969). Soil and bedrock samples are being analyzed for $\mathrm{Al}, \mathrm{C}$ (organic and inorganic) $\mathrm{Ca}, \mathrm{Cl}, \mathrm{Ge}, \mathrm{Fe}$ (oxidized and reduced), $\mathrm{K}, \mathrm{Mg}, \mathrm{Na}, \mathrm{P}$, 
Table 5.--Workplan for the Puerto Rico Water, Energy, and Biogeochemical Budgets study

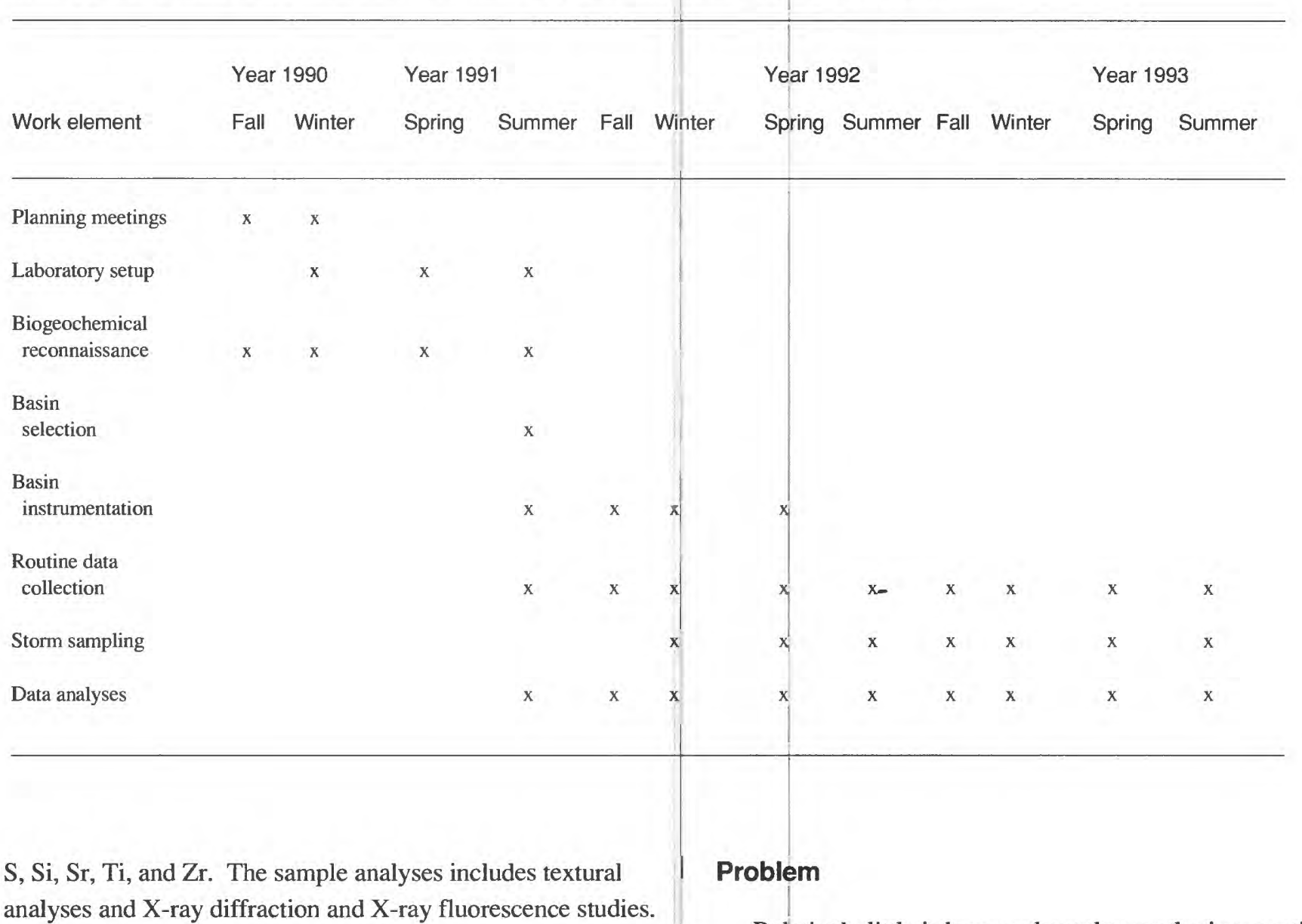

analyses and $\mathrm{X}$-ray diffraction and $\mathrm{X}$-ray fluorescence studies.

Carbon dioxide $\left(\mathrm{CO}_{2}\right)$ and methane $\left(\mathrm{CH}_{4}\right)$ are analyzed in order to meet several research objectives. A gas chromatograph is used for analyses of gases collected from monitoring probes in the unsaturated zone and gases collected from lakes and agricultural ponds. Strontium and carbon isotopes from rainwater and stream water samples are being analyzed.

Additional isotopic analyses are likely to be conducted during the course of the research. Possible analyses for exotic species might include $\mathrm{Li}$ isotopes for assessment of ion-exchange processes and $\mathrm{Be}$ and $\mathrm{Ga}$ for characterization of soil development.

\section{Biogeochemical Reconnaissance Survey}

A reconnaissance biogeochemical survey was conducted in the spring of 1991 to facilitate the selection of watersheds for intensive monitoring and process research. The principal criterion used for the selection of the study basins was the uniformity of bedrock lithology and the lack of large amounts of sulfide minerals and carbonates.
Relatively little is known about the weathering reactions that promote soil development or the processes controlling gas flux in soils. Detailed studies of these processes are needed in study basins that are both accessible and representative of the larger region in terms of topography and vegetation.

\section{Objectives}

The objectives of the biogeochemical reconnaissance survey were to (1) select suitable watersheds for intensive data collection and process research, and (2) characterize the weathering reactions responsible for the soil compositions.

\section{Approach}

Spatial and temporal sampling of streamwater was used to characterize the composition of waters in streams draining the potential study sites. These data enabled the identification (and subsequent exclusion from consideration) of terrains in which carbonate or sulfide mineralization are present. The solution chemistry and geochemical data compiled during the reconnaissance survey were used to identify the predominant weathering 
reactions. Subsequent instrumentation of selected watersheds will be used to expand the preliminary description of weathering processes to a more widely encompassing silicate weathering model based on the calculation of ionic budgets, fluxes, and weathering rates.

Gas fluxes $\left(\mathrm{CO}_{2}\right.$ and $\left.\mathrm{CH}_{4}\right)$ may be measured using chamber techniques in all principal soil associations in each of the four basic forest types (Brown and others, 1983), to describe the spatial, geologic, and ecologic variability of gas exchanges throughout the study area. The spatial distribution of gas fluxes will be used to identify optimal sites for routine gas-flux measurements. Furthermore, the variation in magnitude of gas fluxes will provide preliminary indications of the controls that soil characteristics (thickness, moisture, and composition) and forest type have on microbial production and consumption of the gases $\mathrm{CO}_{2}, \mathrm{~N}_{2} \mathrm{O}$, and $\mathrm{CH}_{4}$.

\section{Biogeochemical Budgets: Water, Energy, Nutrient, Dissolved Solids, Sediment, and Gas Budgets}

Most of the research initiatives described in the following sections depend on calculations of budgets for water, energy, nutrients, dissolved solids, sediment, and gases based on timeseries measurements in the atmosphere, surface water, soil surface, unsaturated zone, and saturated zone.

\section{Problem}

Intensive process-level research requires the instrumentation of study sites to make the calculation of the biogeochemical budgets possible. These budgets are needed to determine the rates and relative importance of processes.

\section{Objectives}

The objectives of this research element are to (1) calculate water, energy, nutrient, dissolved solids, sediment, and gas budgets, and (2) provide baseline time-series data necessary for the process research elements described in subsequent sections.

\section{Approach}

Two watersheds were instrumented for time-series measurement of physical and chemical components to evaluate budgets of biogeochemical substances in both lithologies. The data-collection programs needed to meet both objectives are similar. The specific instrumentation planned for each watershed is described in the following sections.

\section{Meteorology}

Precipitation, solar radiation, barometric pressure, wind speed and direction, relative humidity, and air temperature are recorded and transmitted by satellite in real time from meteorologic stations located in the Icacos and Mameyes watersheds (fig. 2). Two additional meteorologic stations (one located east and one located west of the LEF) record and transmit the same suite of parameters. At sites in the Icacos and Mameyes watersheds, networks of precipitation collectors are used to monitor both throughfall and stemflow. Automated dry deposition/bulk precipitation samplers located at the sites of the Icacos and Mameyes meteorologic stations are sampled biweekly and during selected storms.

\section{Soil and soil water}

Piezometers and tensiometers have been installed at depths ranging from 0.1 to $5 \mathrm{~m}$ to measure pore pressure and water tension in the soil. Some of these instruments are electronic, and measurements are recorded every 15 minutes on data loggers. The remaining instruments are monitored weekly, and during and after selected storms. Each watershed in the LEF contains an array of 16 recording piezometers. The Icacos watershed contains an array of 28 tensiometers. Instrumentation used to study chemical mass transport through soil is installed at selected sites adjacent to instruments being used to monitor water movement through the soil. Zero-tension lysimeters are used to sample water moving through the profile monthly and during and following rainfall events. The movement of ions supplied to the soil by precipitation or leached from leaf litter will be monitored using ion-exchange bags deployed at the soil surface. Plans may allow the use of permanent gas probes to sample the vertical distribution of gases adjacent to the lysimeters. The gas probes would be sampled biweekly to monthly, and the gases collected analyzed with a gas chromatograph. Gas-flux chambers would be used in each watershed, as well as in other pertinent soils for the biweekly to monthly measurement of $\mathrm{CO}_{2}$ and $\mathrm{CH}_{4}$ fluxes.

Hillslopes in each watershed have been instrumented with a total of 22 Gerlach troughs (Lewis, 1974) and 132 erosion pins (Haigh, 1977) to monitor sediment movement on hillslopes. During selected storm events, several rain-splash cups will be deployed (Morgan, 1978) to provide additional information about fine-scale erosion processes. Each Gerlach trough site has a leaf litter collector and a rainfall (throughfall) collector. The Gerlach trough sites are sampled biweekly. The sampling includes collection of soil for determination of moisture content, soil-runoff water and throughfall for chemistry, and periodic chemical analyses of leaf litter. 


\section{Surface water}

Discharge is monitored at USGS and LTER streamflow gaging stations (figs. 2 and 3). All gages have a stage-discharge rating and stage is recorded every 15 minutes. During storms, stage is recorded more frequently. All information collected from stream gages is relayed by satellite to enable remote monitoring of discharge at the USGS Caribbean District offices and elsewhere. Each stream-gage site is equipped with an automatic water sampler for sample collection during storms. This enables field personnel to focus data-collection efforts on precipitation-collection sites, lysimeter sites, and wells.

\section{Ground Water}

Plans may allow for the installation of piezometers in each watershed along a transect between the ridgetop and riparian zone for biweekly to monthly collection of ground-water samples for chemical analyses. Wells will be drilled to depths up to $11 \mathrm{~m}$ and will be sampled with a portable pump. Some existing wells in and near riparian zones might also be sampled.

\section{Precipitation}

Precipitation is monitored at two to six sites in each basin. Biweekly precipitation samples are collected and analyzed along with samples of streamwater and surface runoff from one to three sites in each basin. Streamwater is sampled intensively during the rising limb of the hydrograph and less intensively along the recession at one to two sites in each basin. The number of surface runoff water samples collected per storm depends on rainfall duration and intensity. These data will be used to relate streamwater chemistry and sediment concentrations to rainfall intensity, duration, and antecedent soil moisture conditions. Additionally, hillslope sediment movement is monitored during these storms using the Gerlach troughs and rain-splash cups described before.

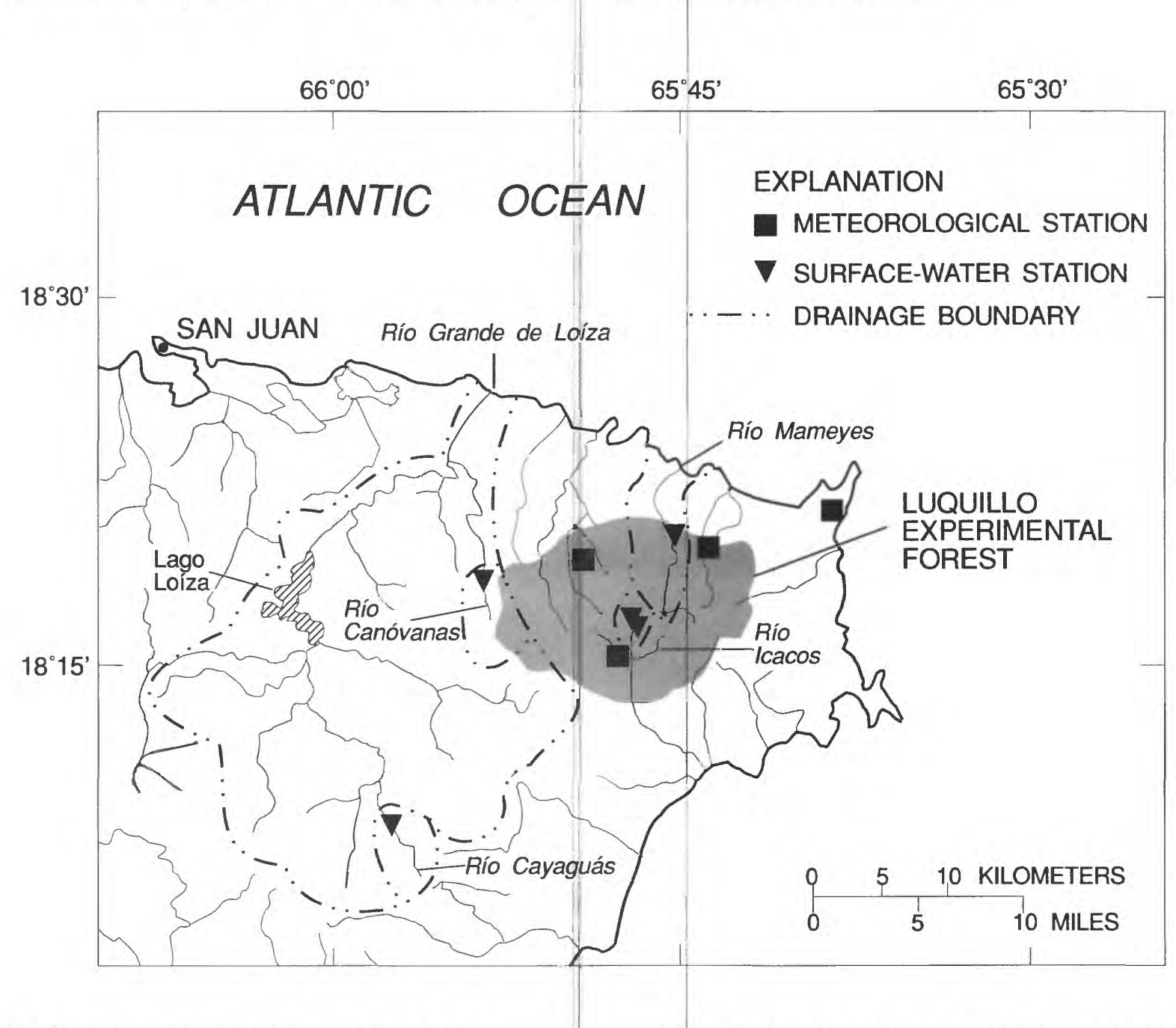

Figure 2. Location of streamflow gaging stations and meteorological stations in and near the Río Grande de Loíza basin and the Luquillo Experimental Forest, northeastern Puerto Rico. 


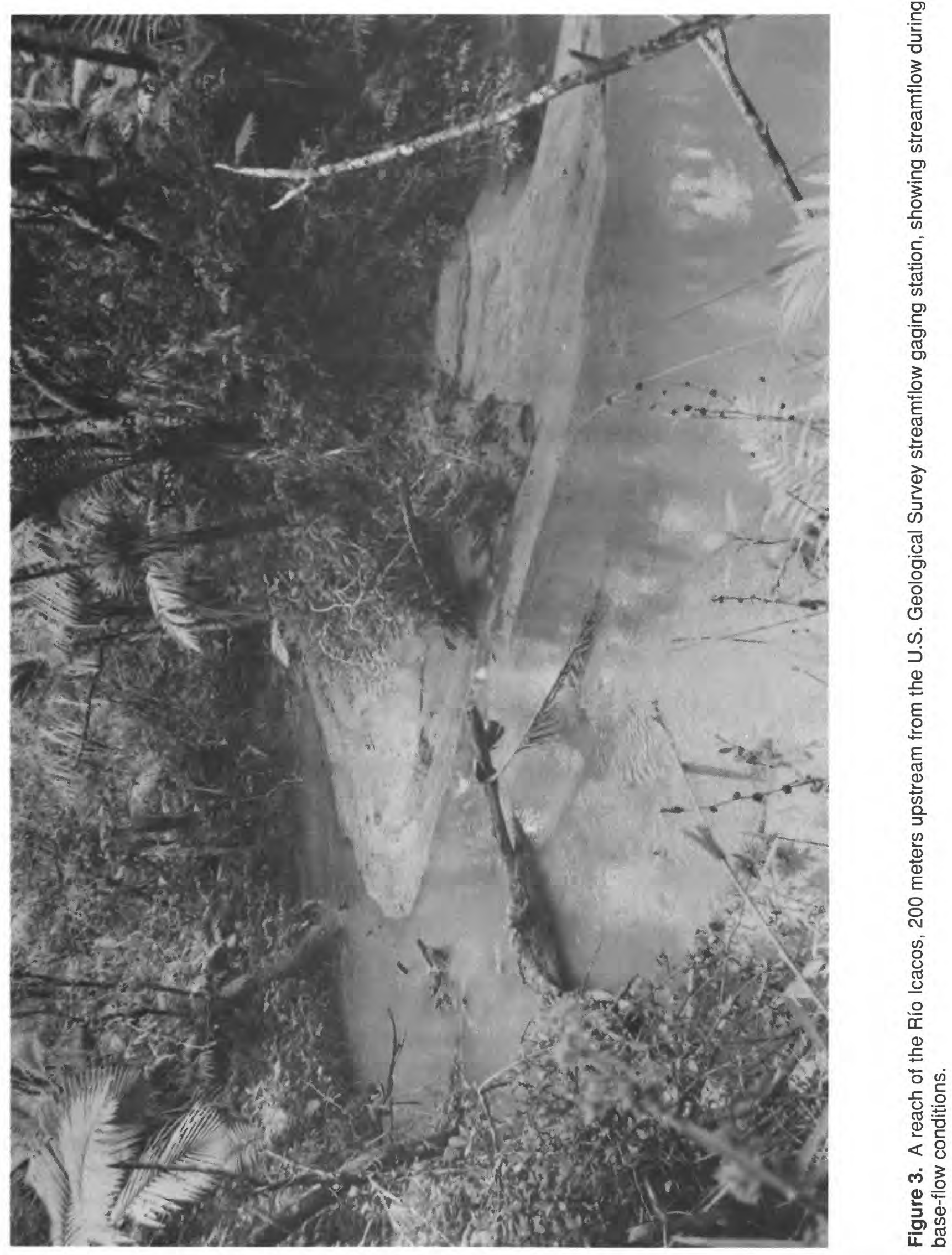




\section{Weathering, Erosion, and Mass-Wasting Processes in Undeveloped Watersheds of Contrasting Bedrock Lithology}

The extent to which chemical and physical weathering and other biogeochemical processes vary as a function of the mineralogy and chemistry of bedrock is essentially unknown for the study area and poorly understood for the humid tropics in general. Research is needed to provide a better understanding of these processes.

\section{Problem}

An improved understanding of the relations between bedrock lithology and biogeochemical processes in the humid tropics is needed to understand the implications of current work to geologic terrains not intensively studied. The physical and chemical characteristics of the dissimilar volcaniclastic and intrusive lithologies in the LEF and the Loíza basin (fig. 1) may exert strong controls on biogeochemical cycling. Lithology indirectly affects biogeochemical cycling through its relatively strong control on geomorphic processes, which in turn directly influence surface and subsurface hydrology. The degree to which bedrock lithology influences the rate of denudation and biogeochemical cycling of substances is not well known.

Notably, Dunne (1978) reports in a study of Kenyan rivers that drain siliceous watersheds with mean-annual runoff ranging from 20 to $2,000 \mathrm{~mm}$, that the wide range of lithology (from basalt to rhyolite, for example) does not have a major effect on the denudation rate.

Mass wasting may play a pivotal role in biogeochemical processes in the humid tropics. The composition of the solid and dissolved loads of rivers draining undeveloped tropicalmontane areas might be controlled by mass-wasting and solifluction processes that mobilize only the less-cohesive soils (Stallard, 1985). Much of the material from mass-wasting events is ultimately deposited in stream channels and removed by fluvial processes. More than 1,800 landslides have been mapped in the LEF, demonstrating that mass wasting is a significant geomorphic process in the forest. Landslides appear to be denuding the landscape at a rate of $190 \mathrm{~mm}$ per 1,000 years, or approximately 239 metric tons per $\mathrm{km}^{2}$ per year (Larsen and Torres-Sánchez, 1992). Simon and Guzmán-Ríos (1990) report that landslides might provide large amounts of bed material for fluvial transport in the upland headwaters of the Loíza basin.

The chemical alteration of primary silicates to clay minerals appears to provide zones in the bedrock and overlying saprolite that promote the development of planes of weakness parallel to slope (St. John and others, 1969; Deere and Patton, 1971). Zones of chemical alteration seem to be related to exfoliation joints developed in bedrock. These planes of weakness are thought to represent a major control in the form and frequency of slope failures. Furthermore, the biogeochemical cycling of nutrients and gases in material transported downslope by mass wasting is not well understood and is likely to have substantially different characteristics than those of undisturbed soils or soils exposed by past landslides.

Landslide scars have biogeochemical cycling characteristics that are different from unaffected slopes (Guariguata, 1990). Studies in Hawaii (Scott, 1975) and Panamá (Garwood and others, 1979) indicate that the recurrence interval and extent of mass wasting are possibly major factors affecting species diversity in tropical forests in landslide-prone areas. A landscape in a geomorphic steady state should neither accumulate nor release carbon or nutrients; however, mass wasting is thought to control carbon and nutrient accumulation in tropical soils by episodically reinitiating the physical, chemical, and biologic processes that promote soil development. Strong feedbacks are likely to exist between vegetation cover, soil thickness, and chemical weathering rates (Stallard, 1985 and 1988). Landslide scars might function as long-term sinks for atmospheric $\mathrm{CO}_{2}$, if soil carbon in the landslide debris is not subsequently oxidized. This terrestrial sink for $\mathrm{CO}_{2}$ could be important for climatologists trying to evaluate global $\mathrm{CO}_{2}$ budgets. Although biogeochemical processes probably return to pre-landslide conditions as the landslide scar is revegetated and redevelops a soil mantle, the natural perturbation of the system might result in an alteration of biogeochemical processes (gas flux; nutrient availability) over thousands to tens of thousands of years. Because the majority of slopes in the LEF are in some stage of recovery from historic and prehistoric mass-wasting processes, there is a need to understand how biogeochemical processes change as a function of the recovery of landslide scars. Landslides in the LEF constitute an ideal natural laboratory for characterizing the processes controlling large-scale interactions among the atmosphere, biosphere, and hydrosphere within mountainous humid-tropical terrains in general.

Specific questions this research will address include the following:

1. What are the chemical reactions, nutrient types, and ionic species that are important in decomposing bedrock in the two different lithologies in the LEF?

2. What erosive processes (sheet, rill, rain-splash, gully erosion, soil creep, mass wasting) transport solid material downslope to valley bottoms, and what is the composition of the transported material? 
3. What is the rate and relative importance of these transport processes?

4. How do weathering rates and reactions differ between soils exposed on mass-wasting scars and undisturbed soils?

5. What happens to carbon and plant nutrients in soils subject to mass wasting as compared to stable soils?

6. Does material stored as colluvium or alluvium undergo significant further weathering before it is transported out of the system?

\section{Objectives}

The objectives of the weathering processes research include the following:

(1) Compare water, energy, biogeochemical, and sediment budgets from the Mameyes watershed, which drains volcaniclastic rocks, and the Icacos watershed, which drains quartz diorite, and determine the effects of bedrock lithology on biogeochemical process interactions.

(2) Develop a conceptual model describing biogeochemical process interactions occurring on mass-wasting scars through time as a function of bedrock lithology and landslide type.

(3) Describe the biogeochemical cycling differences between mass-wasting scars and undisturbed soils, and the biogeochemical characteristics of different parts of individual landslides, including the headscarp, exposed failure plane, and the transported colluvium at the base of the landslide.

\section{Approach}

A comprehensive evaluation of the weathering reactions typical of each rock type will be made on the basis of the composition of stream water, stream sediment, bedrock, and soil. Budgets calculated from time-series data in the Mameyes and Icacos watersheds will be compared to evaluate biogeochemical dissimilarities. The importance of each rock type in contributing $\mathrm{P}$, and possibly $\mathrm{Ca}$ and $\mathrm{K}$ to biota will be evaluated on the basis of the chemistry of the rocks and soils and the gas-flux characteristics of the two watersheds. The parallel study of two fundamentally different rock types, both of which are widely distributed throughout the tropics, enhances process-level research.

Isotopic studies within these two areas of different rock types will be considered for four purposes:

1) to constrain mass balances and reaction models,

2) to assist in the identification of minerals that are weathering,

3) to provide estimates of rates of processes, and
4) to enable the distinction between organic and inorganic processes.

Isotopes, which can be measured in either solid-phase or aqueous samples, include ${ }^{13} \mathrm{C}$ and ${ }^{14} \mathrm{C},{ }^{87} \mathrm{Sr},{ }^{10} \mathrm{Be},{ }^{34} \mathrm{~S},{ }^{15} \mathrm{~N},{ }^{6} \mathrm{Li}$, and ${ }^{238} \mathrm{U} / 234 \mathrm{U}$ disequilibrium. The pseudo-isotope of $\mathrm{Si}--\mathrm{Ge}$ will be evaluated in stream water. Ga may also be studied as a psuedoisotope of Al. Oxygen and hydrogen isotopes are inappropriate because of poor isotopic definition resulting from the low latitude and proximity of the ocean to the study area.

From the group of more than 1,800 landslides that have been mapped in the LEF, several landslides were selected for sampling of soil and saprolite and for measuring gas fluxes. This information provides a means of comparing the biogeochemical signatures of mass-wasting events.

The bracketing of landslides by aerial photography provides an estimate of landslide age to within 10 to 15 years. Landslides predating aerial photographs for the LEF (1930's) can be dated by geomorphic evidence and by estimating the age of vegetation on the landslide scar. After the selection of several landslides for intensive scrutiny and the selection of two unaffected slopes for control studies, a detailed soil sampling program will be instituted. Mineralogy and chemistry will be assessed in various parts of landslides and to varying depths in the soil and saprolite. Soil-monitoring equipment was emplaced at selected sites for spatial and temporal analysis of soil moisture, soil-gas composition, and biogeochemical gas fluxes. Lysimeters were emplaced for collection of monthly composites of soil water. All measured parameters will be statistically related to the age of the landslide in an attempt to describe the transformation of biogeochemical processes through time.

The quartz diorite and granodiorite exposed in portions of the study area are mineralogically similar to (1) granodiorite exposed at the WEBB site at Panola Mountain, Georgia (Hooper and others, 1990); (2) granite at the Loch Vale, Colorado, WEBB site (Baron and Bricker, 1987); and (3) granitic terrain in California, where weathering processes are currently being studied by USGS researchers (Harden and Taylor, 1983).

The volcaniclastic rocks are similar to watersheds being studied in Panamá in conjunction with the Puerto Rico WEBB study (see Collaborative Research section). Comparisons of weathering reactions and rates in humid-tropical, humidtemperate, alpine, and semi-arid-temperate climates will be made on the basis of independent research efforts in the respective study areas. 


\section{Comparison of Weathering and Gas Flux in Developed and Forested Watersheds}

The effects of human disturbance of tropical ecosystems need to be described and quantified in order to assess climatologic, geomorphic, and ecologic responses to the rapid destruction of tropical forests worldwide by the expansion of agriculture and the harvesting of trees.

\section{Problem}

Puerto Rico resembles typical tropical environments climatologically and geologically more than any other area within the United States. It, therefore, provides an accessible location for the study of the effects of degradation of, and land-use changes in the humid-tropical environment. Humid-tropical ecosystems occupy 25 percent of the earth's land surface, yet the global importance of tropical biogeochemical interactions is disproportionately greater than the fraction of land surface covered. Rivers in the humid tropics are responsible for 50 percent of the water, 65 percent of the dissolved silica, 38 percent of the dissolved ions, and 58 percent of the dissolved organic carbon entering the oceans from land (Milliman and Meade, 1983). These rivers account for 30 to 50 percent of the suspendedsediment discharge to the oceans. Estimates of carbon reserves vary, but between 25 percent and 56 percent of global biomass is in tropical forests, and as much as 42 percent of terrestrial carbon-dioxide fixation may occur there. Land clearing by burning in the tropics may reduce biosphere nitrogen fixation by 9 to 20 percent. Much of the world's population growth in the indefinite future is expected to be in the humid tropics (United Nations Educational, Scientific, and Cultural Organization, 1990). This growth is accompanied by unprecedented conversion of natural landscapes into agricultural lands.

Cycling of water in tropical forests typically involves infiltration into shallow soil layers, return of water to the atmosphere through transpiration, and subsequent return of water to the biosphere through precipitation. Deforestation causes soil compaction, increases runoff, and decreases transpiration. Reduced transpiration results in reduced precipitation; the self-perpetuating decrease in the volume of water available within the ecosystem could promote desertification. Once forests are removed from Amazonia, their return might be impossible in the modified (drier) hydrologic regime (Shukla and others, 1990). No comparative studies of evapotranspiration in developed and undeveloped watersheds have been published that quantify the effects of deforestation on biogeochemical processes.
Deforestation, urbanization, and other land-use practices are widely recognized to increase sediment yields in the tropics by an order of magnitude or more (Douglas, 1967; Rapp, 1977; Richardson, 1980). This effect has been described in the Loíza basin (Gellis, 1991). Because soils are an important reservoir for biogeochemically active substances, their removal by erosion has direct implications on nearly all biogeochemical cycling. Tropical soils are often depleted in base cations and nutrients. Slash and burn practices typical of some tropical agricultural nations attempt to ameliorate the nutrient poverty of the soil by recovering (as ash) the nutrients present in vegetation. These nutrients are, in turn, leached into rivers and ground water.

The clearing of land strongly affects fluxes of important gases. Burning of vegetation oxidizes carbon to $\mathrm{CO}_{2}$ and decreases the diurnal $\mathrm{CO}_{2}$ uptake and $\mathrm{O}_{2}$ production by plants. This also results in reduced methane consumption by bacteria in soils (Keller and others, 1991). The creation of agricultural ponds in these cleared areas provides new sources of methane. Land clearing and subsequent application of fertilizers to agricultural areas can increase the production of nitrous oxide in soils (Keller and others, 1991).

Gas emissions and uptake of $\mathrm{CO}_{2}$ and $\mathrm{N}_{2} \mathrm{O}$ have been examined by Keller and others (1986). They report that tabonuco forests are a strong source for $\mathrm{N}_{2} \mathrm{O}$ and a sink for $\mathrm{CH}_{4}$, whereas palo colorado, mountain palm, and dwarf forests are weak $\mathrm{N}_{2} \mathrm{O}$ sources and moderate to strong $\mathrm{CH}_{4}$ sources.

\section{Objective}

The objective of this phase of the research is to compare the processes of physical and chemical weathering, biological gas flux and evapotranspiration in two forested watersheds and in two watersheds that have been converted to pasture and farmland. A study of the composition of stream water draining these watersheds will enable an understanding of the effects of land use changes on the physical and chemical processes in the humid tropics.

\section{Approach}

Paired basins have been selected from forested areas of the LEF (Mameyes and Icacos watersheds) and from agriculturally developed parts of the adjacent Loíza basin (Río Canóvanas and Río Cayaguás watersheds, fig. 1). Stream water chemistry and sediment concentration in all four watersheds are monitored biweekly and during selected storms. On a more limited scale, soil chemistry and mineralogy from the developed watersheds will be examined with techniques described above for investigations in the LEF. 
Gas fluxes in agricultural areas may be evaluated through spatial and temporal measurement of $\mathrm{CO}_{2}, \mathrm{NO}_{2}$, and $\mathrm{CH}_{4}$. The dissimilarities between the gas fluxes of the developed and forested areas should provide a diagnostic indication of the effects of fertilization on increasing $\mathrm{NO}_{2}$ emissions from the soil. The effects of deforestation on the presumed decrease in $\mathrm{CH}_{4}$ consumption of soils will be quantifiable in this manner. Similarly, the comparison should reveal the effects of agricultural development on $\mathrm{CO}_{2}$ flux.

A comparison of biogeochemical budgets calculated from data collected in the two forested and two developed watersheds will enable the quantitative distinction between the fluxes in natural and human disturbed settings. The results should yield valuable insight into the effects of perturbation on the metabolic, chemical, and physical processes that control such fluxes in the tropical environment.

\section{Reservoir and Agricultural Pond Gas Fluxes}

A methane budget for northeastern Puerto Rico is needed to evaluate differences between methane production and consumption in forested and developed parts of the basin. Methane release from tropical areas accounts for at least 50 percent of atmospheric methane (Fung and others, 1991). Most soils contain methanotrophic bacteria; the rate of consumption of methane typically exceeds the rate of production at anaerobic microsites in the soil. Methanogenesis is normally significant only in the sediments of shallow, standing water. In Panamá, the bacteria in one hectare of shallow pond or lake produce approximately the same amount of methane that is consumed by soil bacteria in 400 hectares of pristine forest (Stallard, 1988). Budgeting of methane, therefore, is highly sensitive to spatially restricted inputs from shallow inland water bodies.

\section{Problem}

Few studies have documented the sources and rates of methane production and consumption in the humid tropics. Because of the major land-use changes occurring in the humid tropics at the present time, much information is needed.

\section{Objective}

The objective of the pond gas-flux research is to develop a methane budget for northeastern Puerto Rico. Additionally, various methane sources and sinks will be described and compared.

\section{Approach}

The consumption of methane will be quantified during the preliminary reconnaissance survey and subsequent gas-flux analyses. Methane production will be estimated from fluxes of methane in the Lago Loíza (fig. 1) and in shallow impoundments used for agricultural and livestock purposes throughout the Loíza basin. Additionally, methane production will be measured in ponds created by landslide-blocked tributaries in the LEF. Outgassing from these impoundments will be quantified using inverted funnel-shaped bubble collectors. A gas chromatograph will be used to determine the composition of evolved gases and to characterize the metabolic processes that cause outgassing from submerged sediments.

\section{COLLABORATIVE RESEARCH}

An objective of the WEBB program is to foster cooperative efforts within the USGS, as well as federal-interagency and federal-university research cooperation. The WEBB multidisciplinary approach is strengthened by these interactions, some of which are described below.

\section{Kinetics of Water-Rock Interaction: Puerto Rico}

Studies parallel to the main thrust of the Puerto Rico WEBB research in the Icacos watershed are being directed by a group of USGS geochemists in Menlo Park, California (Arthur White, Alex Blum, Marjorie Schulz, and Thomas Bullen). They are concentrating on mechanisms affecting biogeochemistry on spatially small scales, through the soil zone and across the soilrock interface. This involves the characterization of soil water and chemical fluxes, and calculation of weathering rates of specific primary minerals based on controls, which affect surface reaction, surface areas, fluid chemistry, and secondary mineral formation. It is envisioned that the resulting data can be compared with, and integrated into, watershed-wide processes and mass-balance models.

Specific activities include:

1) Three instrumentation nests, including zero-tension and tension water samplers, tensiometers, and gas samplers, were installed at ridge top and hillslope locations in the Icacos watershed. Two rainfall collectors and one throughfall collector were also installed at the site. Rainfall data from a tipping-bucket raingage at a streamflow gaging station located several hundred meters east of the instrumentation nests are transmitted by satellite.

2) During installation of the site, soil cores were collected for measurement of water content and hydraulic 
conductivity using centrifuging methods developed by the unsaturated-zone research group at Menlo Park.

3) Bulk solid-state chemistry of the soils will be analyzed. Strain models, (Brimhall and Dietrich, 1987) will be used to calculate volumetric and elemental losses from the soils. These results will be compared to mass losses based on mineral variability.

4) The primary mineralogy was characterized by the USGS Mineral Separation Laboratory in Menlo Park, and bulk chemical and isotopic analyses including $\mathrm{Sr}, \mathrm{Ca}, \mathrm{Li}, \mathrm{Pb}$, in addition to the rare earths, were done. The surface chemistry, surface area, and morphology of specific types of minerals, including $\mathrm{K}$-feldspar, plagioclase, hornblende, and micas will be characterized by Brunauer, Emmett, and Teller (BET) method, Transmission Electron Microscopy (TEM), X-ray Photoelectron Spectroscopy (XPS), atomic force microscopy, and other methods, at Menlo Park and the Center for Material Characterization at Stanford University, Palo Alto, California.

5) Experimental dissolution studies will be run on separated mineral phases, principally feldspars, to determine reaction rates of natural materials.

6) NETPATH-type models (Plummer and others, 1991), using chemical fluxes and isotopic variations in the water and soils, will be constructed to quantify weathering rates. These rates will be compared to the time dependent data from the chronosequence study and to other WEBB sites exposed to different climatic conditions.

\section{Smithsonian Tropical Research Institute: Panamá}

Robert Stallard, Ellen Axtmann, and Deborah Martin, USGS, Boulder, Colorado, have been involved in a variety of research projects over the past 5 years in cooperation with the Smithsonian Tropical Research Institute (STRI) in Panamá. These research projects involve the investigation of biogeochemical processes in a humid tropical environment. The Barro Colorado Nature Monument in Panamá is maintained by the STRI and is the site of this research. The objective of this National Aeronautics and Space Administration-supported research was to study methane production and consumption in different environments (forests, swamps, and lakes), and to study methane flux related to different hydrologic conditions (Keller and others, 1991). Two parallel studies were developed in conjunction with this project. One study is of weathering, erosion, and soil formation on Barro Colorado Nature Monument (Johnsson and Stallard, 1989). Numerous samples of soils, stream sediments, and water from streams, rain, and soils were analyzed. The second study used hydrologic, meteorologic, and land-use data from the Panamá Canal basin for studies of global climate change. An 80-year time series of hydrologic data is maintained by the Panamá Canal Commission and STRI for sites within the hydrologic basin of the Panamá Canal, including the Barro Colorado Nature Monument.

A new project, funded by the Environmental Studies Program of STRI, was begun by Stallard in 1991, in parallel to the Puerto Rico WEBB program. The objective of this project is to use long-term chemical sampling to characterize the processes that control the distribution and transport of major, important minor, and nutrient elements $(\mathrm{Al}, \mathrm{C}, \mathrm{Ca}, \mathrm{Cl}, \mathrm{F}, \mathrm{Fe}$, $\mathrm{Ge}, \mathrm{H}, \mathrm{K}, \mathrm{Mg}, \mathrm{Mn}, \mathrm{N}, \mathrm{Na}, \mathrm{O}, \mathrm{P}, \mathrm{S}, \mathrm{Si}, \mathrm{Sr}, \mathrm{Ti}$, and $\mathrm{Zr}$ ) through the surface environment of Barro Colorado Island. Solid, dissolved, and gaseous phases will be analyzed. Two watersheds will be monitored. One stream drains an andesite plateau (not subject to landslides) and can be compared directly to the watershed on quartz diorite in Puerto Rico. The other stream drains a steeply sloping terrain underlain by marine volcaniclastic bedrock and limestone. Soils are thin and contain abundant expanding clays (montmorillonite), which are not abundant in the study areas of Puerto Rico.

\section{Long-Term Ecological Research: Puerto Rico}

The USGS staff have a history of collaboration with numerous LEF research efforts. The National Science Foundation-funded Long-Term Ecological Research Program, initiated in 1988, has fostered this cooperation and resulted in the interactions listed below.

Meteorologic stations: Frederick Scatena, hydrologist with the U.S. Dept. of Agriculture, Institute of Tropical Forestry (ITF) worked with the USGS staff to site, construct, and instrument four meteorologic stations in and east of the LEF. The meteorologic stations were purchased by the ITF and installed by the USGS. The stations transmit by satellite to the USGS satellite receiving station in San Juan, Puerto Rico. Meteorologic data from these stations and an additional USGS meteorologic station in the Río Icacos valley are shared by the USGS and the ITF.

Effects of Hurricane Hugo: A joint ITF/USGS publication (Scatena and Larsen, 1991) details some of the physical effects of the 1989 hurricane on the LEF and describes an index for comparing hurricanes that have affected Puerto Rico during the past 100 years.

Soil chemistry: Matthew Larsen, USGS, assisted University of Pennsylvania Geology Professor, Arthur Johnson, 
and Ph.D. student, Daniel Zarig, in locating and describing landslide sites in the LEF for soil sampling.

Landslide modeling: Matthew Larsen is working with State University of New York, Syracuse, College of Environmental Science and Forestry, Professor Charles Hall, and graduate students, Neil Pederson and Edwin Everham, in the testing and evaluation of an LEF landslide prediction model.

\section{Puerto Rico Department of Natural Resources/ University of Puerto Rico}

The USGS collaborates with researchers from island-based institutions and is currently involved in a joint study of runoff effects on corals. Richard M. Webb, USGS, is directing the investigation in cooperation with the Puerto Rico Department of Natural Resources and the University of Puerto Rico researchers on the effects of runoff and sedimentation on coral vitality at the mouth of the Río Grande de Loíza. Water-quality data generated by the WEBB project at the Río Canóvanas will be utilized in the coral study.

\section{USGS/Puerto Rico Aqueduct and Sewer Authority Lago Loíza Basin Uplands Erosion}

A joint USGS/Puerto Rico Aqueduct and Sewer Authority study of erosion processes in the uplands of the Lago Loíza basin was begun in 1990. Lago Loíza, the principal water supply for San Juan, is experiencing rapid siltation resulting from urbanization and industrialization in the basin. The joint study, directed by Richard M. Webb, with William J. Wolfe, and Allen C. Gellis, USGS, monitors sediment yield at 12 sites in the basin. These sites are located on hillslopes under pasture, crop, forest, and active construction, and are instrumented with Gerlach troughs and erosion pins. Stream sediment is monitored on several rivers in the basin, including the Río Cayaguás.

\section{Centre National de la Recherche Scientifique, Campus Orsay, France}

The study of the cosmogenic radionuclides, ${ }^{10} \mathrm{Be}(\mathrm{t}+=1.5$ Myr) and ${ }^{26} \mathrm{Al}(\mathrm{t}+=0.7 \mathrm{Myr})$, in quartz provides an independent estimate of long-term denudation rates. These radionuclides are produced near the ground surface by cosmic rays striking soils and bedrock. Quartz is used because of its resistance to chemical weathering and its chemical purity. It will be assumed that denudation in the Río Icacos watershed has been steady for the last 100,000 years. To estimate in situ production of cosmogenic ${ }^{10} \mathrm{Be}$ and ${ }^{26} \mathrm{Al}$, in a soil profile, one needs to know altitude, aspects, and approximate soil composition. A Geographic Information System (GIS) model of the basin will be used to calculate in situ production over the entire basin and to predict the average cosmogenic isotopic composition of quartz being transported out of the basin. Major disagreement between measured and predicted composition would refute a steady-state hypothesis. In addition, the predicted isotopic composition of quartz from various landform elements (peaks, ridges, slopes, valley floors) will be compared with samples from those elements. A high degree of variance in measured isotopic composition from a particular landform element would indicate long periods of stability, followed by rapid erosion (for example, mass wasting). Eric T. Brown of Centre National de la Recherche Scientifique will be working with Stallard and Larsen in this effort.

\section{Center for Marine Science, University of Southern Mississippi, Stennis Space Center}

The geochemistry of aluminum in the weathering process and in streams is of interest, because it is a major earth element. Aluminum interacts with phosphorus and organic carbon, it is an important soil colloid, and it may be toxic in certain situations. The crustal geochemistry and solution chemistry of gallium are similar to that of aluminum. Gallium has been used as a less reactive analogue for aluminum and allows for the study of factors influencing the weathering and stream behavior of aluminium. This study builds on the concepts developed by Murnane and Stallard (1990) to describe the effects of chemical weathering and erosion on silicon. Here, germanium and silicon form an elemental pair analogous to aluminium and gallium.

A proposal submitted to the National Science Foundation (NSF) by Alan M. Shiller, Center for Marine Science, University of Southern Mississippi, Stennis Space Center, would continue previous NSF-funded research on the geochemistry of gallium relative to aluminum in streams and in the weathering process. This proposal, endorsed by Larsen and Stallard in letters to the NSF, includes time series data collection of stream waters in the LEF and several sites in (1) the southwestern U.S. (carbonate basins in west Texas or New Mexico), (2) an organic-rich basin in the southeastern U.S., (3) volcanic drainages in the Pacific Northwest, and (4) other WEBB sites or experimental forests, if cooperative arrangements can be made. The sampling of highly weathered solids that occur in tropical watersheds may help to establish an upper limit for the mobilization of aluminum to the dissolved phase. This three-year study would begin in June 1993. Work that Stallard is doing on germanium and silicon in the study basins will be compared with the work of Shiller. 
Anderson, M.G., 1983, Road-cut slope topography and stability relationships in St. Lucia, West Indies: Applied Geography, v. 3, p. 105-114.

Anderson, M.G., and Burt, T.P., 1978, The role of topography in controlling throughflow generation: Earth Surface Processes, v. 3, p. 331-344.

Anderson, M.G., and Kneale, P.E., 1980, An examination of the relationship between storm precipitation and pore water conditions in road cut slopes, St. Lucia, West Indies: Singapore Journal of Tropical Geography, v. 1, no. 1, p. 1-8.

Baron, J.A., and Bricker, O.P., 1987, Hydrologic and chemical flux in the Loch Vale watershed, Rocky Mountain National Forest, Colorado, in Averett, R.C., and McKnight, D., eds., Chemical Characteristics of Water and Hydrologic Cycle: Lewis Publishers, Ann Arbor, Michigan.

Baynton, H.W., 1968, The ecology of an elfin forest in Puerto Rico, 2, The microclimate of Pico del Oeste: Journal of Arnold Arboretum, v. 49, no. 4, p. 419-430.

Beaven, P.J., and Dumbleton, M.J., 1966, Clay minerals and geomorphology in four Caribbean islands: Clay Minerals, v. 6, p. 371-382.

Beinroth, F.H., 1971, The general pattern of the soils of Puerto Rico: Transactions, Fifth Caribbean Geological Conference, Bulletin No. 5, p. 225-230.

1982, Weathered soils of Puerto Rico, 1. Morphology, formation, and classification: Geoderma, v. 27, p. 1-73.

Birdsey, R.A., and Weaver, P.L., 1987, Forest area trends in Puerto Rico: U.S. Department of Agriculture, Forest Service Research Note SO-331, 5 p.

Boccheciamp, R.A., 1977, Soil survey of the Humacao area of eastern Puerto Rico: U.S. Department of Agriculture, Soil Conservation Service, $103 \mathrm{p}$.

1978, Soil survey of San Juan area of Puerto Rico: U.S. Department of Agriculture, Soil Conservation Service, $141 \mathrm{p}$.

Bogart, D.B., Arnow, Ted, and Crooks, J. W., 1964, Water Resources of Puerto Rico, A progress report: U.S. Geological Survey Water Resources Bulletin No. 4, 90 p.

Briggs, R.P., and Akers, J.P., 1965, Hydrogeologic map of Puerto Rico and adjacent islands: U.S. Geological Survey Hydrologic Investigations Atlas HA-197, 1 sheet, 1:240,000.

Brimhall, G.H., and Dietrich, W.E., 1987, Constitutive, mass balance, and strain in metasomatic hydrochemical systems: Results on weathering and pedogenesis: Geochimica Cosmochimica Acta, v. 51, p. 567-587.
Briscoe, C.B., 1966, Weather in the Luquillo Mountains of Puerto Rico: U.S. Department of Agriculture, Forest Service, Research Paper ITF-3, 250 p.

Broedel, C.H., 1961, Preliminary geologic map showing iron and copper prospects in the Juncos quadrangle, Puerto Rico: U.S. Geological Survey Miscellaneous Geologic Investigations Map I-326, 1 sheet, 1:240,000 scale.

Brown, Sandra, Lugo, A.E., Silander, Susan, and Liegel, Leon, 1983, Research history and opportunities in Luquillo Experimental Forest: U.S. Department of Agriculture, Forest Service, General Technical Report SO-44, 128 p.

Brown, Sandra, and Lugo, A.E., 1984, Biomass of tropical forests: A new estimate based on forest volumes: Science, v. 223, p. 1290-1293.

Calvesbert, R.J., 1970, Climate of Puerto Rico and the U.S. Virgin Islands: U.S. Department of Commerce, Climatography of the United States, no. 60-52, 29 p.

Cardona, W.A., 1984, El Yunque mineral prospects, eastern Puerto Rico: Caribbean Journal of Science, v. 20, p. 79-87.

Collar, P.D., Troester, J.W., Deike, R.G., and Robinson, P.D., 1990, Iron and manganese in alluvial ground water, Yabucoa, Puerto Rico: Interamerican Association of Sanitary and Environmental Engineers Proceedings, San Juan, Puerto Rico, Sept. 9-14, 1990, v. 3, p. 708-732.

Colón, J.A., 1983, Algunos aspectos de la climatología de Puerto Rico: Acta Científica, v. 23, p. 55-63.

Curtis, R.E., Aquino, Zaida, Díaz, P.L., and Vachier, R.J., 1991, Water Resources Data-Puerto Rico and the U. S. Virgin Islands: U.S. Geological Survey Water-Data Report PR 90-1, 514 p.

Dames and Moore, Inc., 1980, Report on the Rehabilitation of Río Blanco Hydroelectric Project for Puerto Rico Electric Power Authority: Houston, Texas, Job No. 11905-002-14, 77 p.

Deere, D.U., and Patton, F.D., 1971, Slope stability in residual soils, in 4th Panamerican Conference on Soil Mechanics and Foundation Engineering, Proceedings: American Society of Civil Engineers, v. 1, p. 87-170.

Dixon, H.H., and Robertson, R.H.S., 1970, Some engineering experiences in tropical soils: Quarterly Journal of Engineering Geology, v. 3, no. 3, p. 137-150.

Douglas, Ian, 1967, Natural and man made erosion in the humid tropics of Australia, Malaysia, and Singapore: International Association of Scientific Hydrology, v. 75, p. 31-39.

Dunne, Thomas, 1978, Rates of chemical denudation of silicate rocks in tropical catchments: Nature, v. 274, no. 5668, p. 244-246. 
Edmisten, Joe, 1970, Soil studies in the El Verde rain forest, in Odum, H.T., and Pigeon, R.F., eds., A tropical rain forest: U.S. Department of Commerce, National Technical Information Service, Springfield, Virginia, p. H79-H87.

Ewel, J.J. and Whitmore, J.L., 1973, The ecological life zones of Puerto Rico and the U.S. Virgin Islands: U.S. Department of Agriculture, Forestry Service Research Paper ITF-18, $72 \mathrm{p}$.

Fung, Inez, John, J.A., Lerner, Jean, Matthews, Elaine, Prather, Michael, Steele, L.P., and Fraser, P.J., 1991, Threedimensional model synthesis of the global methane cycle: Journal of Geophysical Research, v. 96, no. D7, p. 13,03313,065 .

Frangi, J.L., and Lugo, A.E., 1985, Ecosystem dynamics of a subtropical floodplain forest: Ecological Monographs, v. 55, no. 3, p. 351-369.

Garwood, N.C., Janos, D.P., and Brokaw, Nicholas, 1979, Earthquake-caused landslides: A major disturbance to tropical forests: Science, v. 205, p. 997-999.

Gellis, Allen, 1991, Construction effects on sediment for two basins in Puerto Rico, in The Fifth Interagency Sedimentation Conference, Proceedings: Las Vegas, Nevada, March 18-21, 1991, Chap. 4, p. 72-78.

Gray, W.M., 1984, Atlantic seasonal hurricane frequency, Part 1: El Niño and $30 \mathrm{mb}$ quasi-biennial oscillation influences: Monthly Weather Review, v. 112, p. 1,649-1,668.

Guariguata, M. R., 1990, Landslide disturbance and forest regeneration in the upper Luquillo mountains of Puerto Rico: Journal of Ecology, v. 78, p. 814-832.

Guariguata, M.R, and Larsen, M.C., 1990, Preliminary map showing landslides in El Yunque quadrangle, Puerto Rico: U.S. Geological Survey Open-File Report 89-257, 1 pl.

Guy, H.P., 1969, Laboratory theory and methods for sediment analysis: U.S. Geological Survey Techniques of WaterResources Investigations, Book 3, Chap. C2, 59 p.

Haigh, M.J., 1977, The use of erosion pins in the study of slope evolution: British Geomorphological Research Group Technical Bulletin 18, p. 31-49.

Harden, J.W., and Taylor, E.M., 1983, A quantitative comparison of soil development in four climatic regimes: Quaternary Research, v. 20, p. 342-359.

Hernández-Santana, J.R., Bouza-Alonso, O.B., González-Ortíz, Rodolfo, and Magaz-García, Antonio, 1988, Pronóstico geomorfológico de ocurrencia de deslizamientos en la Sierra Maestra, Cuba: Publicación de la Academía de Ciencias de Cuba, Instituto de Geografía, 14 p.

Hooper, R.P., Christophersen, N.N., and Peters, N.E., 1990, Modeling stream water chemistry as a mixture of soil-water end members--An application to Panola Mountain, Georgia, USA: Journal of Hydrology, v. 116, p. 321-343.
Hupp, C.R., 1983, Seedling establishment on a landslide site: Castanea, v. 48, p. 89-98.

Johnsson, M.J., and Stallard, R.F., 1989, Physiographic controls on the composition of sediments derived from volcanic and sedimentary basins on Barro Colorado Island, Panamá: Journal of Sedimentary Petrology, v. 59, no. 5, p. 768-781.

Jordan, C.F., 1970a, Flow of soil water in the lower montane tropical rain forest, in Odum, H.T., and Pigeon, R.F., eds., A tropical rain forest: U.S. Department of Commerce, National Technical Information Service, Springfield, Virginia, p. H199-H200.

$1970 \mathrm{~b}$, Movement of ${ }^{85} \mathrm{Sr}$ and ${ }^{134} \mathrm{Cs}$ by the soil water of a tropical rain forest, in Odum, H.T., and Pigeon, R.F., eds., A tropical rain forest: U.S. Department of Commerce, National Technical Information Service, Springfield, Virginia, p. H201-H204.

Jordan, C.F., Kline, J.R., and Sasscer, D.S., 1972, Relative stability of mineral cycles in forest ecosystems: American Naturalist, v. 106, p. 237-253.

Jürgen, M.L., Scharffe, D.H., Hao, W.M., and Crutzen, P.J., 1990 , Importance of biomass burning in the atmospheric budgets of nitrogen-containing gases: Nature, v. 346, p. 552-554.

Keller, Michael, Kaplan, W.A., and Wofsy, S.C., 1986, Emission of $\mathrm{N}_{2} \mathrm{O}, \mathrm{CH}_{4}$, and $\mathrm{CO}_{2}$ from tropical forest soils: Journal of Geophysical Research, v. 91, p. 11,791-11,802.

Keller, Michael, Mitre, M.E., and Stallard, R.F., 1991, Consumption of atmospheric methane in soils of central Panamá--effects of agricultural development: Global Biogeochemical Cycles, v. 4, no. 1, p. 21-27.

Kline, J.R., and Odum, H.T., 1970, Comparisons of the amounts of fallout radionuclides in tropical forests, in Odum, H.T., and Pigeon, R.F., eds., A tropical rain forest: U.S. Department of Commerce, National Technical Information Service, Springfield, Virginia, p. H181-H186.

Larsen, M.C., and Simon, Andrew, 1990, Landslide processes in saprolitic soils of a tropical rain forest, Puerto Rico, in Larue, D.K., and Draper, G., eds., Transactions of the 12th Caribbean Geological Conference, St. Croix, U.S. Virgin Islands: Miami Geological Society, p. 217-222.

Larsen, M.C., and Torres-Sanchez, A.J., 1990, Rainfall-soil moisture relations in landslide-prone areas of a tropical rain forest, Puerto Rico, in Krishna, J.H., Quiñones-Aponte, Vicente, Gómez-Gómez, Fernando, and Morris, G. L., eds., Tropical Hydrology and Caribbean Water Resources: Proceedings of the International Symposium on Tropical Hydrology and Fourth Caribbean Islands Water Resources Congress, p. 121-130. 
Larsen, M. C., and Torres-Sanchez, A. J., 1992, Landslides triggered by Hurricane Hugo in eastern Puerto Rico, September 1989: Caribbean Journal of Science, v. 28, no. 3-4, p. 113-125.

Leigh, Jr., E.G., Rand, A.S., and Windsor, D.M., eds., 1982, The ecology of a tropical forest-- seasonal rhythms and long-term changes: Washington, D.C., Smithsonian Institution Press, $468 \mathrm{p}$.

Lewis, L.A., 1974, Slow movements of earth under tropical rainforest conditions: Geology, v. 2, p. 9-10.

1985, Assessing soil loss in Kiambu and Murang'a districts, Kenya: Geografiska Annaler, v. 67A, no. 3-4, p. 273-284.

López, M.A., Colón-Dieppa, Eloy, and Cobb, E.D. 1979, Floods in Puerto Rico, magnitude and frequency: U.S. Geological Survey Water-Resources Investigation Report 78-141, $70 \mathrm{p}$.

Lugo-López, M.A., Juárez Jr., J.J., and Bonnet, J.A., 1968, Relative infiltration rate of Puerto Rican soils: Journal of Agriculture, University of Puerto Rico, v. 52, p. 233-240.

Malayan Nature Society, 1978, Productivity of terrestrial rainforest, The Malaysian International Biological Program Synthesis Meetings: Malayan Nature Journal, v. 30, no. 2, p. 114-447.

Miller, J.F., 1965, Two- to ten-day rainfall for return periods of 2 to 100 years in Puerto Rico and Virgin Islands: Weather Bureau, U.S. Department of Commerce, Technical Paper $53,36 \mathrm{p}$.

Milliman, J.D., and Meade, R.H., 1983, World-wide delivery of river sediment to the oceans: Journal of Geology, v. 91, p. 1-21.

Monroe, W.H., 1977, Geologic map of the Carolina Quadrangle, Puerto Rico: U.S. Geological Survey Miscellaneous Geologic Investigations Map I-1054, 1 sheet, 1:20,000 scale.

1979, Map showing landslides and areas of susceptibility to landsliding in Puerto Rico: U.S. Geological Survey Miscellaneous Investigations Map Series I-1148, 1 sheet, $1: 240,000$ scale.

Morgan, R.P.C., 1978, Field studies of rain-splash erosion: Earth Surface Processes, v. 3. p. 33- 44.

Mosquera, Menandra, and Feheley, JoAnne, 1984, Bibliography of forestry in Puerto Rico: U.S. Department of Agriculture, Forest Service, General Technical Report SO-51, $196 \mathrm{p}$.

Murnane, R.J., and Stallard, R.F., 1990, Germanium and silica in rivers of the Orinoco drainage basin, Venezuela, and Colombia: Nature, v. 344, p. 749-752.

Musk, L.F., 1988, Weather Systems: Cambridge, England, Cambridge University Press, 160 p.
Odum, H.T., Lugo, A.E., Cintrón, Gilberto, and Jordan, C.F., 1970, Metabolism and evapotranspiration of some rain forest plants and soil, in Odum, H.T., and Pigeon, R.F., eds., A tropical rain forest: U.S. Department of Commerce, National Technical Information Service, Springfield, Virginia, p. I103-I164.

Odum, H.T., and Pigeon, R.F., 1970, A tropical rain forest: Springfield, Virginia: U.S. Department of Commerce, National Technical Information Service, 1,678 p.

Ortíz, C.A., 1974, Relationship between engineering properties and topographical expression for the rocks in Río de la Plata's valley walls, Comerío, Puerto Rico: 2nd International Conference of the International Association of Engineering Geology, Proceedings, p. v6.1 to v6.8.

Pease, Jr., M.H., 1968, Geologic map of the Aguas Buenas quadrangle, Puerto Rico: U.S. Geological Survey Miscellaneous Geologic Investigations Map I-479, 1 sheet 1:20,000 scale.

Plummer, N.L., Presestemon, E.C., Parkhurst, P.L., 1991, Interactive code (NETPATH) for modeling net geochemical reactions along a flow path: U.S. Geological Survey WaterResources Investigations Report 91-4078, 227 p.

Quiñones, M.A., 1953, High intensity rainfall and major floods in Puerto Rico: Proceedings of American Society of Civil Engineers, v. 79, no. 364,35 p.

Quiñones-Márquez, Ferdinand, 1978, Selected chemical properties of rainfall in the Río Piedras basin, Puerto Rico: U.S. Geological Survey Open-File Report 78-159, 14 p.

Rapp, A.A., 1977, Soil erosion and reservoir sedimentation: Case studies in Tanzania: Soil Conservation Management in Developing Countries, Soils Bulletin No. 3, Rome, FAO.

Richardson, Jane, 1980, The influence of forest covering on aspects of erosion and streamflow in Mount Airy, eastern Jamaica: Journal of the Geological Society of Jamaica, $v$. 19, p. 35-39.

Rogers, C.L., 1979, Geologic map of the Caguas quadrangle, Puerto Rico: U.S. Geological Survey Miscellaneous Geologic Investigations Map I-1152, 1 sheet, 1:20,000 scale.

Rogers, C.L., Cram, C.M., Pease, Jr., M.H., and Tischler, M.S., 1979, Geologic map of the Yabucoa and Punta Tuna quadrangles, Puerto Rico: U.S. Geological Survey Miscellaneous Geologic Investigations Map I-1086.

Rouse, W.C., and Reading, A.J., 1987, Landslides in strong, highly permeable tropical clay soils of Dominica, West Indies, in Gardiner, J., ed., International Geomorphology, Part 1: London, John Wiley and Sons, Limited, p. 431-464.

Scatena, F.N., 1989, An introduction to the physiography and history of the Bisley experimental watersheds in the Luquillo mountains of Puerto Rico: U.S. Department of Agriculture General Technical Report SO-72, 22 p. 
1990, Watershed scale rainfall interception on two forested watersheds in the Luquillo mountains of Puerto Rico: Journal of Hydrology, v. 113, p. 89-102.

Scatena, F. N., and Larsen, M. C., 1991, Physical aspects of Hurricane Hugo in Puerto Rico: Biotropica, v. 23, no. 4A, p. 317-323.

Scott, G.A.J., 1975, Relationships between vegetation cover and soil avalanching in Hawaii: Proceedings of the Association of American Geography, v. 7, p. 208-212.

Seiders, V.M., 1971a, Geologic map of the El Yunque quadrangle, Puerto Rico: U.S. Geological Survey Miscellaneous Geologic Investigations Map I-658, 1 sheet, $1: 20,000$ scale.

1971b, Geologic map of the Gurabo quadrangle, Puerto Rico: U.S. Geological Survey Miscellaneous Geologic Investigations Map I-657, 1 sheet, 1:20,000 scale.

Shukla, J.B., Nobre, C.E., and Sellers, P.T., 1990, Amazon deforestation and climate change: Science, v. 247, p. 1,322-1,325.

Simon, Andrew, and Guzmán-Ríos, Senén, 1990, Sediment discharge from a montane basin, Puerto Rico--Implications of erosion processes and rates in the humid tropics, in Research Needs and Applications to Reduce Erosion and Sedimentation in Tropical Steeplands: International Association of Hydrologic Science Publication No. 192, p. 35-47.

Simon, Andrew, Larsen, M.C., and Hupp, C.R., 1990, The role of soil processes in determining mechanisms of slope failure and hillslope development in a humid-tropical forest: eastern Puerto Rico, in Kneuper, P.L.K., and McFadden, L.D., eds., Soils and Landscape Evolution: Geomorphology, v. 3, p. 263-286.

Sowers, G.F., 1971, Landslides in weathered volcanics in Puerto Rico: 4th Panamerican Soil Mechanics and Foundation Engineering Conference, Proceedings, v. 2, p. $105-115$.

St. John, B.J., Sowers, G.F., and Weaver, C.E., 1969, Slickensides in residual soils and their engineering significance: Seventh International Conference on Soil Mechanics and Foundation Engineering, Mexico, v. 2, p. 591-597.
Stallard, R.F., 1985, River chemistry, geology, geomorphology, and soils in the Amazon and Orinoco basins, in Drever, J.I., ed., The Chemistry of Weathering: Dordrecht, Holland, Reidel Publishing Co., p. 293-316.

1988, Weathering and erosion in the humid tropics, in Lerman, A., and Meybeck, M,. eds., Physical and Chemical Weathering in Geochemical Cycles: Dordrecht, Holland, Kluwer Academic Publishers, p. 225-246.

Stallard, R.F., and Edmond, J.M., 1983, Geochemistry of the Amazon 2: The influence of the geology and weathering environment on the dissolved load: Journal of Geophysical Research, v. 88, p. 9,671-9,688.

Tannehill, I.R., 1956, Hurricanes, their nature and history, particularly those of the West Indies and the southern coasts of the United States: Princeton, New Jersey, Princeton University Press, $308 \mathrm{p}$.

United Nations Educational, Scientific, and Cultural Organization, 1990, Water-related issues and problems of the humid tropics and other warm humid regions: Paris, France, United Nations Environment Programme, 33 p.

U.S. Department of Commerce, 1961, Generalized estimates of probable maximum precipitation and rainfall-frequency data for Puerto Rico and the Virgin Islands: Technical Report No. 52, 94 p.

1959-1988, Storm Data: National Oceanographic and Atmospheric Administration, v. 1 - 30.

1982, Census (1980) of population and housing: Puerto Rico: U.S. Department of Commerce, Bureau of Census, PHC80-V-5, p. 53-1 to 53-11.

Walsh, R.P.D., 1980, Runoff processes and models in the humid tropics: Zeitschrift für Geomorphologie, Supplemental Bulletin 36, p. 176-202.

Wentworth, C.K., 1943, Soil avalanches on Oahu, Hawaii: Bulletin of the Geological Society of America, v. 54, p. 53-64.

White, A.F., and Peterson, M.L., 1990, Role of reactivesurface-area characterization in geochemical kinetic models, in Melchior, D.C., and Bassett, R.L., eds., Chemical Modeling of Aqueous Systems II: American Chemical Society Symposium Series 416, p. 461-475.

Young, A.A., 1960, Soil movement by denudational processes on slopes: Nature, v. 188, p. 120-122. 